\title{
Recent Advancement in Nanotechnology-Based Drug Delivery System Against Viral Infections
}

\author{
Deepak Pradhan, ${ }^{1}$ Prativa Biswasroy, ${ }^{1}$ Amit Goyal, ${ }^{2}$ Goutam Ghosh, ${ }^{1}$ and Goutam Rath ${ }^{1,3}$
}

Received 30 September 2020; accepted 18 December 2020; published online 14 January 2021

\begin{abstract}
In the last few decades, the exponential rise in the incidence of viral infections sets a global health emergency across the world. The biomimetic architecture, the ability to hijack host immune responses, continuous antigen shifting, and drafting are the major critical factors that are responsible for the unavailability of a concrete therapeutic regimen against viral infections. Further, inappropriate pharmacodynamic physicochemical and biological parameters such as low aqueous solubility, poor permeability, high affinity for plasm proteins, short biological half-lives, and fast elimination from the systemic circulation are the major critical factors that govern the suboptimal drug concentration at the target site that leads to the development of drug resistance. To address this issue, nanotechnology-based drug delivery approach is emerged as an altering method to attain the optimal drug concentration at the target site for a prolonged period by integrating the nanoengineering tools in the synthesis of nanoparticles. Nanodimensional configuration with enhanced permeability and retention effect, increased surface-area-to-volume ratio, provision for surface functionalization, etc., are the privileged aspects that make it an effective drug delivery system for dispensing the antiviral therapeutics. However, size, shape, charge, and surface topology of nanoparticles are the greater influential factors that determine target-specific drug delivery, optimum cellular uptake, degree of opsonization by the host immune cells, drug retention time, transcytosis, the extension of biological half-life, in vivo stability, and cytotoxicity. The review will enlighten the elaborative role of nanotechnology-based drug delivery and the major challenging aspect of clinical safety and efficacy.
\end{abstract}

KEY WORDS: antiviral; therapeutic nanoparticles; organic and inorganic nanocarrier system; pharmacokinetics; targeted delivery.

\section{Highlights}

- The last few decades, viral infections set a global health emergency across the world.

- Conventional delivery of antiviral drugs with inappropriate pharmacodynamic parameters is the foremost reason for substandard therapeutic outcomes risk of multidrug resistance.

- Nanodimensional configuration with enhanced permeability and retention effect, increased surface-area-to-volume ratio, provision for surface functionalization, etc., are the privileged aspects that make it an effective drug delivery system for dispensing the antiviral therapeutics.

- Despite the overwhelming understanding of the various advantage of nanotechnology-based drug delivery systems, their reproducibility, in vivo stability, and toxicity are the great concern for accessing clinical safety and efficacy.

Communicated by: Claudio Salomon

${ }^{1}$ School of Pharmaceutical Sciences, Siksha 'O' Anusandhan University, Bhubaneswar, Odisha, India.

${ }^{2}$ School of life sciences, Central University Rajasthan, Ajmer, India.

${ }^{3}$ To whom correspondence should be addressed. (e-mail: goutamrath123@gmail.com)

\section{INTRODUCTION}

In the last few decades, epidemiologic studies reveal the emerging incidences of viral infections have significantly increased worldwide. A vibrant example of the latest pandemic outbreak of the novel coronavirus shows the catastrophic impact on millions of people around the world with negative health and socio-economic growth. The lack of antiviral therapies for measles, rubella, chickenpox/shingles, SARS-CoV, MERS-CoV, chikungunya virus, Ebola virus, and Zika virus was successively exemplified in the twenty-first century [1]. The development of an effective treatment against viral infections remains a greater challenging arena in front of the global scientific community. The various critical factors like continuous viral antigen shifting and drafting (alteration of surface proteins (antigen) due to mutation), non-specific drug targeting, suboptimal drug concentration at the target site, and development of drug resistance are the crucial factors that are responsible for ineffective therapeutic regimen against viral infections [2]. The major antiviral drug 
regimen consists of remdesivir, oseltamivir, zidovudine, zalcitabine, stavudine, abacavir, nelfinavir, ritonavir, efavirenz, etc., which have been used in routine practice for the treatment of various viral infections. However, inappropriate physicochemical and biopharmaceutical parameters like poor aqueous solubility, sub-optimized plasma drug concentration at the target site/low bioavailability, less drug residence time in plasma/shorter half-life, poor permeability, and undesirable side effects restrict their full-fledged clinical utility in the treatment against viral infections. Detailed information regarding physicochemical properties of some of the antiviral therapeutic agents is mentioned in Table I. For example, zidovudine, nucleoside reverse transcriptase inhibitors used in pregnant women to prevent passing the HIV, loses considerable potency as the drug undergoes significant hepatic first-pass metabolism (40\%) and then rapidly eliminated from the body with a biological half-life of $1 \mathrm{~h}$ [28]. Besides, drugs like nevirapine, delavirdine, efavirenz, and etravirine belong to the family of nonnucleoside reverses transcriptase inhibitors (NNRTIs) used in the treatment of HIV which possess poor oral bioavailability that limits their constant therapeutic concentration at the target site. Adherence to the patient treatment a high dose burden of therapeutics such as fosamprenavir $1400 \mathrm{mg}$ twice daily, nelfinavir $1250 \mathrm{mg}$ twice daily (10 tablets daily), and amprenavir $1200 \mathrm{mg}$ three times daily (16 tablets daily) remain in the routine practice [29]. This may lead to hepatotoxicity, hyperglycemia, hyperlipidemia, lactic acidosis, lipodystrophy, osteonecrosis, osteoporosis, osteopenia, skin rashes, etc. on prolonged treatment with the antiviral drug regimen [30]. Literature reveals that such prolonged antiviral therapy triggers the silent risk of secondary microbial (especially caused by infections, etc.) [31]. Recently, remdisivir is an RNA-dependent RNA polymerase inhibitor recommended in the treatment of COVID-19 that shows 2$11 \%$ liver dysfunction with an increased level of aspartate aminotransferase and alanine aminotransferase [32]. Further, drugs like stavudine (1.3-1.4 h), abacavir (0.8-1.5 h), and nelfinavir (3.5-5 h) are the short half-life drugs that required frequent dosing leading to poor patient compliance [33]. Other class of antiviral therapeutics such as acyclovir, ritonavir, and efavirenz shows poor aqueous solubility 2.25, 1.2 , and $8.85 \mu \mathrm{g} / \mathrm{L}$ respectively at $\mathrm{pH} 6.8$ which restrict their systemic absorption from the intestinal site that leads to poor drug bioavailability [34, 35]. Addressing such issues, nanotechnology-based drug delivery is emerging as an alternative approach for improving the therapeutic efficiency by altering the physicochemical properties of the antiviral drugs. Tracking the effectiveness and safety profile, there are still many critical aspects like immunogenicity, target specificity, and compatibility in the biological environment that are closely associated with the nanotechnology-integrated nanomedicines. In contrast, viruses have been armed with a different strategy to evade humoral and cellular immune responses for about millions of years of evolution [36]. Viral physiochemical features that include size, shape, hydrophobicity, and surface charge define many of these stealth activities.

Table I. Physicochemical Properties Some of the Antiviral Therapeutic Agents

\begin{tabular}{|c|c|c|c|c|c|c|}
\hline Sl. no. & Name of the drug & Dose & Aqueous solubility & Half-life & Bioavailability & Reference \\
\hline & Oseltamivir & $75 \mathrm{mg}$ orally once daily & $10 \mathrm{mg} / \mathrm{ml}$ & $6-10 \mathrm{~h}$ & 4 to $17 \%$ & {$[3]$} \\
\hline & Remdesivir & $200 \mathrm{mg}$ on day 1 & $2.17 \mathrm{mg} / \mathrm{mL}$ & $0.89 \mathrm{~h}$ & - & [4] \\
\hline & Stavudine & $40 \mathrm{mg}$ twice daily & $83 \mathrm{mg} / \mathrm{mL}$ & $1.3-1.4 \mathrm{~h}$ & $68-104 \%$ & {$[5]$} \\
\hline & Zalcitabine & $0.750 \mathrm{mg}$ every $12 \mathrm{~h}$ & $2 \mathrm{mg} / \mathrm{ml}$ & $2 \mathrm{~h}$ & $70-80 \%$ & [6] \\
\hline & Zidovudine & $600 \mathrm{mg} /$ day & $28.90 \mathrm{mg} / \mathrm{mL}$ & $0.5-3 \mathrm{~h}$ & $64 \%$ & [7] \\
\hline & Abacavir & $600 \mathrm{mg}$ daily & $77 \mathrm{mg} / \mathrm{mL}$ & $0.8-1.5 \mathrm{~h}$ & $83 \%$ & [8] \\
\hline & Nelfinavir & $1250 \mathrm{mg}$ orally twice a day & $0.00201 \mathrm{mg} / \mathrm{mL}$ & $3.5-5 \mathrm{~h}$ & $40-80 \%$ & [9] \\
\hline & Ritonavir & $100 \mathrm{mg}$ once daily & $0.1 \mathrm{mg} / \mathrm{ml}$ & $3-5 \mathrm{~h}$ & 60 to $80 \%$ & [10] \\
\hline & Efavirenz & $300 \mathrm{mg}$ orally & less than $10 \mathrm{mg} / \mathrm{L}$ & $52-76 \mathrm{~h}$ & $40-45 \%$ & [11] \\
\hline & Delavirdine & $400 \mathrm{mg}$ orally 3 times a day & $0.086 \mathrm{mg} / \mathrm{mL}$ & $5.8 \mathrm{~h}$ & $85 \%$ & [12] \\
\hline & Etravirine & $200 \mathrm{mg}$ orally twice a day & $0.07 \mathrm{mg} / \mathrm{ml}$ & $40 \mathrm{~h}$ & $33-37 \%$ & {$[13]$} \\
\hline & Amprenavir & $1200 \mathrm{mg}$ twice daily & $0.5 \mathrm{mg} / \mathrm{ml}$ & $7.7 \mathrm{~h}$ & $>70 \%$ & {$[14]$} \\
\hline & Acyclovir & $400 \mathrm{mg}$ every $12 \mathrm{~h}$ & 1.2 to $1.6 \mathrm{mg} / \mathrm{mL}$ & $2.9 \mathrm{~h}$ & $10-20 \%$ & {$[15]$} \\
\hline & Ganciclovir & $1.25 \mathrm{mg} / \mathrm{kg}$ IV day & $4.3 \mathrm{mg} / \mathrm{mL}$ & $2-6 \mathrm{~h}$ & $8.5 \%$ & [16] \\
\hline & Valganciclovir & $900 \mathrm{mg}$ twice daily & $70 \mathrm{mg} / \mathrm{mL}$ & $18 \mathrm{~h}$ & $60 \%$ & [17] \\
\hline & Lamivudine & $300 \mathrm{mg}$ orally once daily & $276.08 \mathrm{mg} / \mathrm{mL}$ & $5-7 \mathrm{~h}$ & $86 \%$ & {$[18]$} \\
\hline & Adefovir & 10 mg orally daily & $0.4 \mathrm{mg} / \mathrm{mL}$ & $10.2 \mathrm{~h}$ & $59 \%$ & [19] \\
\hline & Telbivudine & $600 \mathrm{mg}$ orally every $48 \mathrm{~h}$ & $>20 \mathrm{mg} / \mathrm{mL}$ & $14 \mathrm{~h}$ & $68 \%$ & {$[20]$} \\
\hline & Entecavir & $0.5 \mathrm{mg}$ orally once daily & $2.4 \mathrm{mg} / \mathrm{mL}$ & $15 \mathrm{~h}$ & At least $70 \%$ & {$[21]$} \\
\hline & Tenofovir & $8 \mathrm{mg} / \mathrm{kg}$ orally once a day & $13.4 \mathrm{mg} / \mathrm{mL}$ & $17 \mathrm{~h}$ & $25 \%$ & {$[22]$} \\
\hline & Emtricitabine & $200 \mathrm{mg}$ once daily orally & $112 \mathrm{mg} / \mathrm{mL}$ & $10 \mathrm{~h}$ & $80 \%$ & {$[23]$} \\
\hline & Atazanavir & $300 \mathrm{mg}$ once daily orally & $4-5 \mathrm{mg} / \mathrm{ml}$ & $6.74 \mathrm{~h}$ & $60-68 \%$ & {$[24]$} \\
\hline & Lopinavir & $400 \mathrm{mg}$ twice daily & $\sim 5 \mu \mathrm{g} / \mathrm{mL}$ & $5-6 \mathrm{~h}$ & $\sim 25 \%$ & {$[25]$} \\
\hline & Saquinavir & $1000 \mathrm{mg}$ twice daily & $2.22 \mathrm{mg} / \mathrm{mL}$ & $4.3-10.9 \mathrm{~h}$ & $\sim 4 \%$ & [26] \\
\hline & Zanamivir & $10 \mathrm{mg}$ inhaled once daily & $5 \mathrm{mg} / \mathrm{ml}$ & $2.5-5.1 \mathrm{~h}$ & $1-5 \%$ & {$[27]$} \\
\hline
\end{tabular}




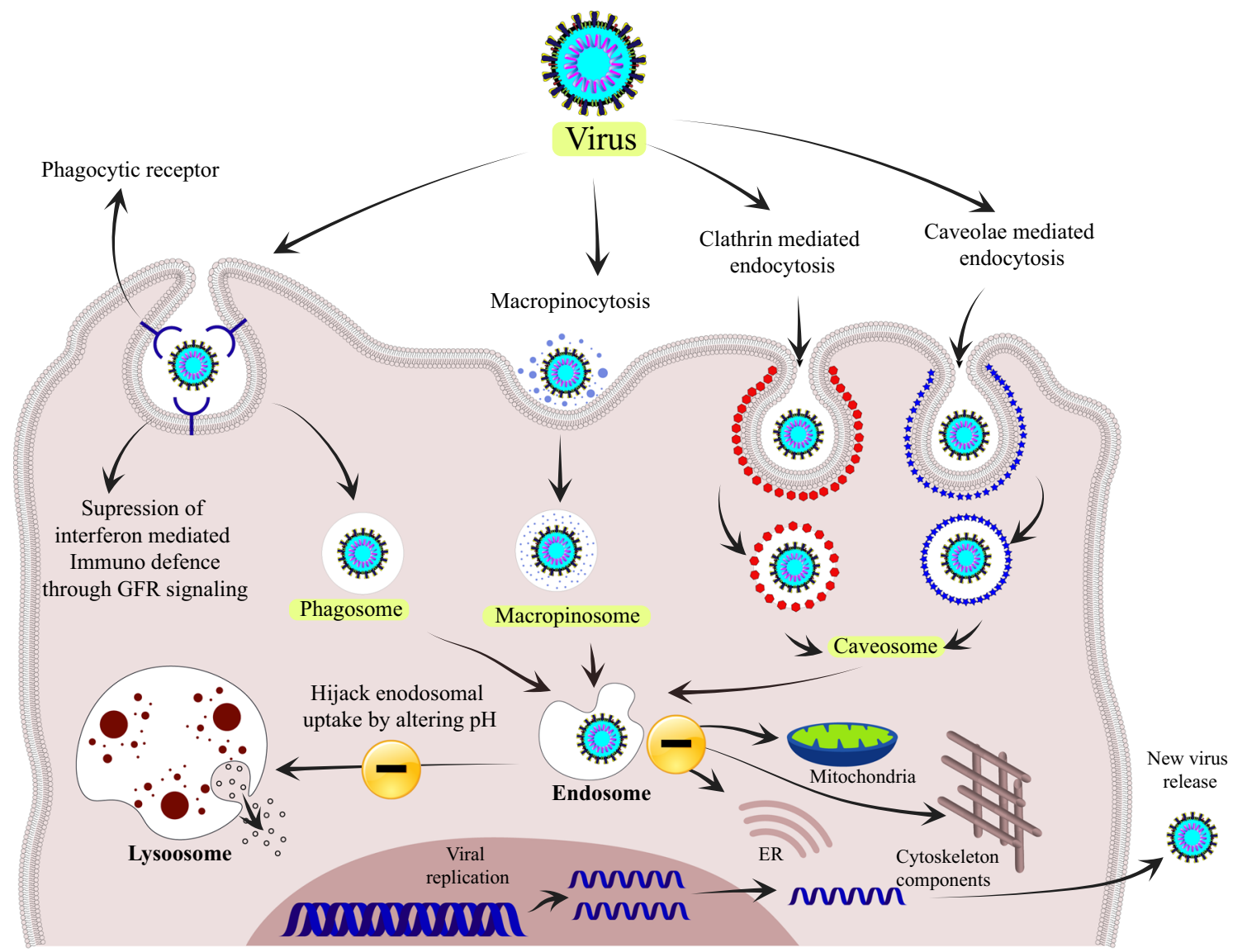

Fig. 1. a Invasion of the virus into the host cell: The various molecular path such as phagocytosis, micropinocytosis, clathrin, and caveola-mediated opt by the virus to enter into the host cell. The bio mimic characteristic feature of the virus enables them to escape from the endosome by altering $\mathrm{pH}$ and host cellular immune responses. $\mathbf{b}$ Intracellular transport of NPs: NPs opt for a similar mechanism as processed by viral particles. After successive internalization through multiple channel port, NPs are trafficked in the endolysosomal network within the endosomal vesicles triggered by motor proteins and cytoskeleton components. NPs are decorated with stimuli-responsive polymers that modulate the "proton sponge effect" to escape from the endosomal vesicles and safely deliver to the cytoplasmic compartment. The virucidal activity NPs with the free generation of ROS inhibit the DNA/RNA replication

\section{VIRUS: NATURE'S MOST DELICATE NANOPARTICLE}

A virus is the microscopic particulate of dimensions ranging from 1 to $100 \mathrm{~nm}$ that fuses directly at the plasma membrane followed by various endocytic processes such as clathrinmediated endocytosis, caveolin-mediated endocytosis, macropinocytosis, and phagocytosis that reach intracellular compartments. After successful internalization of viral components (both enveloped and non-enveloped), it alters the cellular environmental factors, like $\mathrm{pH}$, connection with a target cell, or the activity of proteolytic enzymes, that causes a conformational change in specific proteins that manipulate the host immune responses [37]. The inherent biomimicry tendency of the invading virus inhibits the host cellular immune factors by molecular hijacking or by altering the post-translational modification. Viruses such as mimiviruses with a larger diameter of $760 \mathrm{~nm}$ are invaded through phagocytosis by macrophages, whereas smaller viruses tend to be internalized through clathrin- mediated endocytosis into cells as mentioned in Fig. 1a [38]. Although each virus immune evasion mechanism is different, one of the key factors determining the immune evasion ability of viruses may be the size. Literature suggests that the administration of a single hepatitis B virus (HBV) virion is capable of developing hepatocyte infection in chimpanzees. This could be explained by the endogenous stealth characteristic feature of HBV that escaped from RES. For immune escape, surface charge and hydrophobicity of viral particles are also critical. Cells are more likely to uptake non-ionic particles hydrophobic particles than hydrophilic ones [39]. Positively charged particles have longer circulation times than negatively charged particles, as evidence derived from the pattern virus's circulation life with its surface charge. Virions' surface charge depends on the environment surrounding them. The surface charge of the viral protein varies according to the isoelectric point of the viral protein, which is regulated by the $\mathrm{pH}$ of the environment, from negative to positive. In physiological environments, the bulk of viruses exhibit negatively charged surfaces. Opsonization can be avoided by viruses with negatively charged glycans, leading to 


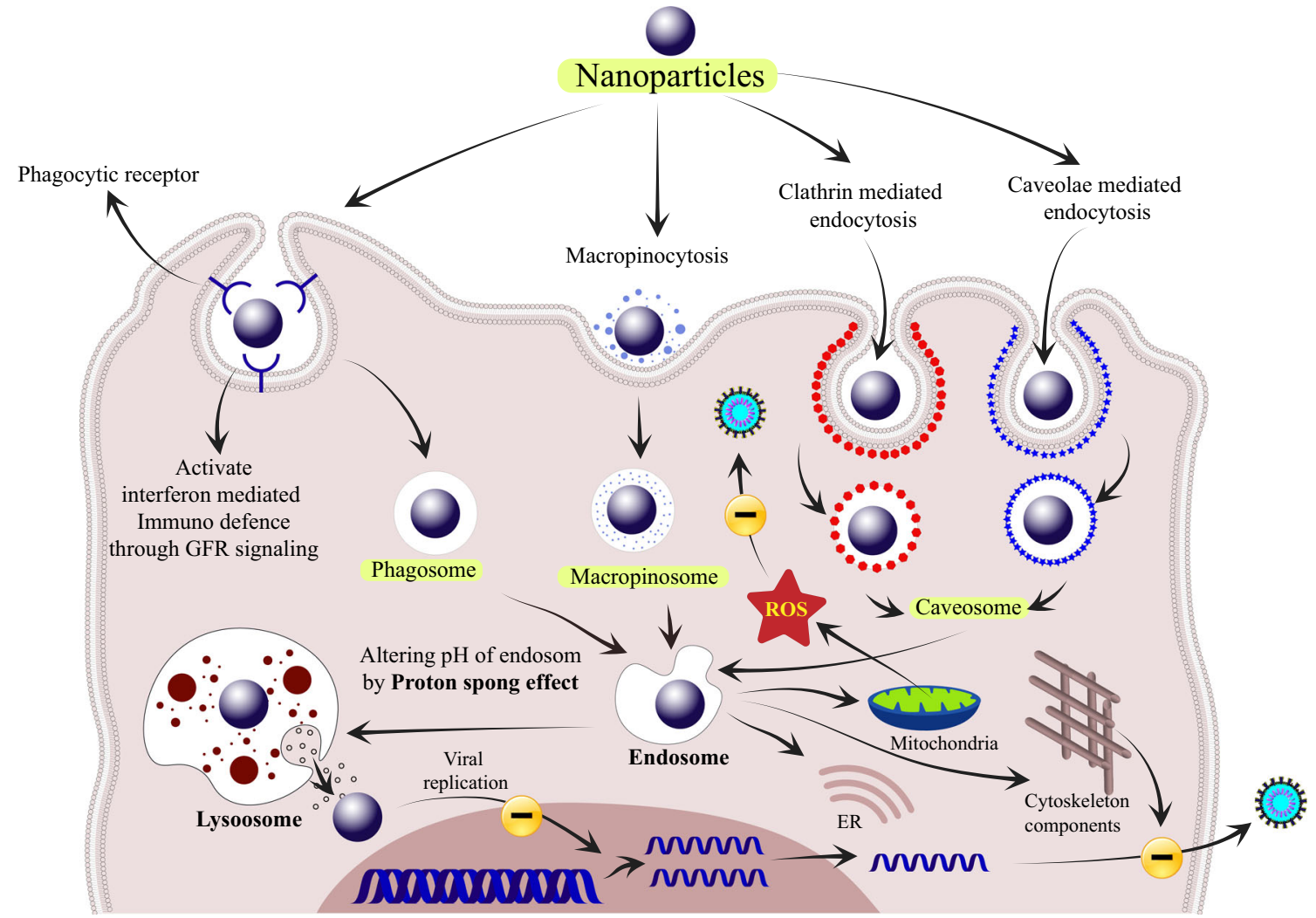

Fig. 1. continued.

escape from phagocytosis [40]. Viruses have several methods to escape from the host immune system; alteration surface protein expression is one of the prime suspects. For example, HBV has a polymerized albumin receptor (PAR) in the pre-S2 region. It has been noticed that the phagocytosis of NPs by Kupffer cells was drastically reduced when NPs were conjugated with peptides containing PAR. Therefore, the recruiting of HSA to the HBV PAR domain (i.e., albumin-coating strategy) could be one of the innovative approaches to encounter the NP clearance, another example citing the surface functionalization of liposome with myristoylated pre-S1(2-47) peptide (for targeting and endosomal escaping activity) and pre-S2(120129) peptide (for stealth activity) to achieve the efficient in vivo delivery in $\mathrm{HBV}$ infection [41].

\section{Nanotechnology-Based Drug Delivery System for the Treatment of Viral Infections}

As per the Center for Disease Control and Prevention (CDC) guidelines, the appearance of widespread resistance against the strains of influenza A viruses adamantanes (amantadine and rimantadine) a class of antiviral drugs used are not recommended by the physicians in the USA. In addition, antiviral drugs like ganciclovir and valganciclovir (cytomegalovirus), acyclovir (herpes simplex virus), lamivudine, adefovir, telbivudine, entecavir, and tenofovir (hepatitis B virus) show clinical evidence for drug resistance [42]. Non-specific cell targeting and suboptimal drug concentration at the target site are the foremost reasons for the development of drug resistance. The resurgence of interest in this arena has led to the development of a smart nanotechnology-based programmable drug delivery system as an alternative approach for sustaining optimal drug concentration at the target site, reducing the dose frequency, enhancing the drug bioavailability and dampening the drug degradation/metabolism, inhibiting the cellular efflux system, and improving cell-targeted drug delivery. Nanodimensional configuration with enhanced permeability and retention effect, increased surface-area-to-volume ratio, ease of surface functionalization for cell targeting, conjugation with biocompatible molecules for prolonged circulation time, etc. are the privileged aspects that make it a promising drug delivery system. Based on the composition, it is broadly divided into organic and inorganic nanocarrier systems (NCs) as described in Fig. 2.

Organic NCs consist of liposomes, dendrimers, carbon nanotubes, micelles, microemulsion, polymeric nanoparticles, etc., which are extensively used to improve drug solubility, permeability, and bioavailability of the antiviral drugs as mentioned in Table II. Further, altering the surface charge and conjugating with the target ligands assist in the cell-targeted drug delivery [52]. For example, $\mathrm{Li}$ et al. synthesized a surfacefunctionalized zidovudine nanoparticle with a series of methoxypoly(ethylene glycol)succinyl derivatives with a different molecular weight ranging from $75 \mathrm{Da}$ to $10 \mathrm{kDa}$ evaluated for the anti-HIV activity. The experimental findings suggest that PEG derivatives with a molecular weight of 750 Da shows a 2-3fold prolonged half-life with $224 \%$ increased drug bioavailability [53]. The antiviral drugs with poor aqueous solubility are improved by embedding nanoparticulate with a suitable polymeric material such as poly(lactic acid), poly(glycolic acid), polycaprolactone, polysaccharides, poly(acrylic acid) family, proteins, and polypeptides (e.g., gelatin) [54]. Mazumder and coworkers synthesized ritonavir nanoparticles with novel cellulose acetate-based polymers. The well-defined particle size of 


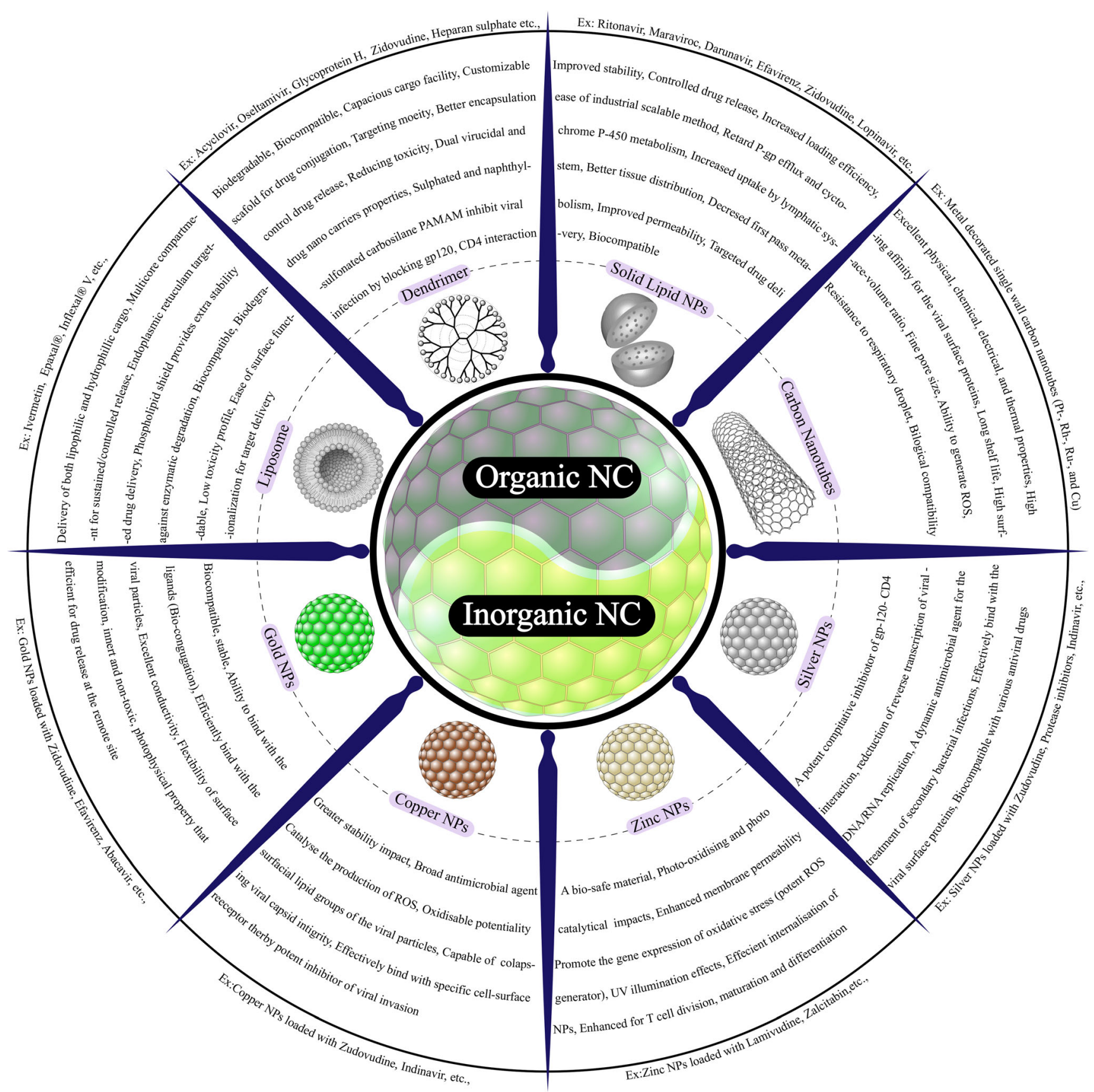

Fig. 2. A schematic diagram elaborate the diversified nanocarrier system in the improvement of physicochemical properties of the antiviral therapeutic agents

100-200 nm with a polydispersity index of approximately 0.2 and drug loading capacity of $88-96 \%$ not only shows improved solubility but also enhanced the drug release profile in comparison with the nude drug. Nanoparticles prepared with cellulose acetate propionate 504-0.2 adipate 0.33 , cellulose acetate propionate adipate 0.85 , and cellulose acetate $320 \mathrm{~S}$ sebacate polymers show approximately $20 \%, 27 \%$, and $30 \%$ of drug release within $5 \mathrm{~h}$ of drug administration respectively [34]. The inorganic NCs include superparamagnetic nanoparticles (iron oxide nanoparticles), quantum dots, and plasmonic nanoparticles (gold and silver nanoparticles) with an average dimension less than organic NCs, i.e., 1-100 nm [55]. Inorganic NCs are widely used to improve the therapeutic efficiency, biodistribution, and pharmacokinetic profiles of the antiviral drugs as mentioned in Table III.

Further, inorganic materials like gold, silver, copper, and zinc are readily internalized by host immune cells like macrophages and dendritic cells and induce their activation which protects the host cell from pathogen invasion [68]. The literature demonstrates broad-spectrum virucidal activities of metal nanoparticles against a wide range of viruses including HIV-1, influenza virus, hepatitis B virus, herpes simplex virus, etc. [59]. 
Table II. Alteration of Physicochemical Parameters of the Antiviral Drugs Formulated with Organic NCs

\begin{tabular}{|c|c|c|c|c|c|c|}
\hline Drug & $\begin{array}{l}\text { Virus } \\
\text { type }\end{array}$ & $\begin{array}{l}\text { Nanoplatform } \\
\text { type }\end{array}$ & $\begin{array}{l}\mathrm{N} \text { a n o p l a t f o r m } \\
\text { characteristics }\end{array}$ & Model & Outcomes & Reference \\
\hline \multicolumn{7}{|c|}{ Liposome } \\
\hline GCV & HSV & $\begin{array}{l}\mathrm{PC} / \mathrm{CH} / \mathrm{NaDC} \\
\mathrm{dissolved} \mathrm{in} \\
\text { chlor of orm / } \\
\text { diethyl }\end{array}$ & $\begin{array}{l}\text { - Reverse phas e } \\
\text { evaporation } \\
\text { - Sephadex G-50, CH } \\
\text { - Spherical liposomes; } \\
\text { - Sizes }(210 \pm 17 \mathrm{~nm})\end{array}$ & $\begin{array}{l}\text { Male and female albino } \\
\text { rabbits ( } 2 \text { to } \sim 2.5 \mathrm{~kg} \text { ) }\end{array}$ & $\begin{array}{l}\text { - Shows } 3.9 \text {-fold higher trans- } \\
\text { corneal permeability than that of } \\
\text { the solution } \\
\text { - AUC profile shows a } 1.7 \text {-fold } \\
\text { higher concentration-time of } \\
\text { GAN liposomes compared with } \\
\text { the observed solution. }\end{array}$ & {$[43]$} \\
\hline PIs & HIV & Pegylated & $\begin{array}{l}-\mathrm{HSPC}, \mathrm{CH}, \mathrm{mPEG}- \\
\text { DSPE } \\
-\mathrm{Mean} \text { diameter of } ~ \\
100 \mathrm{~nm}\end{array}$ & $\begin{array}{l}\text { Human } \mathrm{T} \text { cell lines } \\
\text { HUT78 and PM1 }\end{array}$ & $\begin{array}{l}\text { - Antiviral effect of the F105-L- } \\
\text { PI1 is about } 20 \text {-fold higher than } \\
\text { that of free drug }\end{array}$ & {$[44]$} \\
\hline Indinavir & HIV & Immunoliposomes & $\begin{array}{l}\text { - DPPC, DPPG, DSPE- } \\
\text { PEG-MAL, 14C-DPPC } \\
\text { - Average diameter } \\
(100 \text { and } 120 \mathrm{~nm})\end{array}$ & $\begin{array}{l}\text { - Female } \mathrm{C} 3 \mathrm{H} \text { mice } \\
(18-20 \mathrm{~g}) \text { and adult } \\
\text { male Sprague-Dawley } \\
\text { rats }(200-250 \mathrm{~g})\end{array}$ & $\begin{array}{l}\text { - Drug accumulation (15 days) } \uparrow \\
\text { up to } 126 \text { times in lymph nodes } \\
\text { - No damage to liver and spleen }\end{array}$ & {$[45]$} \\
\hline \multicolumn{7}{|c|}{ Solid lipid nanoparticle } \\
\hline GCV & CMV & Borneol & $\begin{array}{l}\text { - Microemulsion method } \\
\text { - Particle size (113 and } \\
142 \mathrm{~nm}) \\
-\zeta \text {-potential (-15.1 and - } \\
18.3 \mathrm{Mv})\end{array}$ & $\begin{array}{l}\text { Kunming strain mice } \\
(17-22 \mathrm{~g})\end{array}$ & $\begin{array}{l}\text { - GAN-SLN enhance drugs to the } \\
\text { CNS. } \\
\text { - The cumulative \% of GAN } \\
\text { released from SLNs can be up to } \\
80 \% \text { in } 12 \mathrm{~h} \text {. }\end{array}$ & {$[46]$} \\
\hline ATV, PI & HIV & $\begin{array}{l}\text { Stearic acid }+ \\
\text { Poloxamer } 188\end{array}$ & $\begin{array}{l}\text { - Thin-film hydration } \\
\text { technique } \\
\text { - Spherical SLNs with a } \\
\text { mean diameter of } \\
167 \mathrm{~nm}, \zeta \text {-potential } \\
\text { around }-18 \mathrm{mV}\end{array}$ & $\begin{array}{l}\text { Immortalized human } \\
\text { brain microvessel } \\
\text { endothelial cell line } \\
\text { (hCMEC/D3) }\end{array}$ & $\begin{array}{l}\text { - Initial burst release of drug of } \\
\text { approximately } 17 \% \text { by } 1 \mathrm{~h} \text { with a } \\
\text { gradual release up to } 46 \% \text { after } \\
24 \mathrm{~h} \\
\text { - Successive delivery of drug } \\
\text { in vitro to human brain } \\
\text { endothelial cells }\end{array}$ & {$[47]$} \\
\hline Penciclovir & $\begin{array}{l}\text { HSV, } \\
\text { CMV }\end{array}$ & Lyophilization & $\begin{array}{l}\text { - Emulsion technique } \\
\text { - Poloxamer } 188 \text { and Brij } \\
78 \text {, E P C, G M S, } \\
\text { dichloromethane, Tween } \\
\text { 80, and Tween } 20\end{array}$ & $\begin{array}{l}\text { Male Wistar rats }(200 \pm \\
20 \mathrm{~g})\end{array}$ & $\begin{array}{l}\text { - Amount of penciclovir } \\
\text { penetrated into the dermis from } \\
\text { SLNs increased by } 130 \% \\
\text { - SLN-based drug was more than } \\
\text { 2-fold that of the commercial } \\
\text { cream at } 12 \mathrm{~h} \text {. }\end{array}$ & {$[48]$} \\
\hline \multicolumn{7}{|c|}{ Dendrimer } \\
\hline $\begin{array}{l}\text { A C V or } \\
\text { TFV }\end{array}$ & $\begin{array}{l}\mathrm{HSV}- \\
2\end{array}$ & $\begin{array}{l}\text { Poly a nionic } \\
\text { c a r bosilan e } \\
\text { dendrimers }\end{array}$ & $\begin{array}{l}\text { - G1-C8, G1-S4, G3-S16, } \\
\text { G2-NF16, G2-S16, G2- } \\
\text { STE16, G2-CTE16, and } \\
\text { G2-S24P }\end{array}$ & $\begin{array}{l}\text { Female BALB/c mice } \\
6-8 \text { weeks old }(20 \pm 2 \mathrm{~g})\end{array}$ & $\begin{array}{l}\text { - } \downarrow \text { DNA polymerase } \\
\text { - G1-S4 or G2-S16 on topical } \\
\text { vaginal or rectal avoid HSV-2 } \\
\text { transmission }\end{array}$ & {$[49]$} \\
\hline AZT & HIV & $\begin{array}{l}\text { P E T I M } \\
\text { dendrimer }\end{array}$ & Methanol, acetonitrile & $\begin{array}{l}\text { Albino rats }(100-200 \mathrm{~g} \\
\text { in weight), Sprague- } \\
\text { Dawley strain, } 6 \text { to } \\
8 \text { weeks old }\end{array}$ & $\begin{array}{l}\text { - } \downarrow \text { Hemolytic toxicity } \\
\text { - Sustained drug release from } \\
\text { dendrimer } 6.5 \pm 0.3 \% \text { and } 95.8 \pm \\
4.1 \% \text { is the control drug solution. } \\
\text { - Application of AZT-dendrimer } \\
\text { shows 4-fold higher after } 6 \mathrm{~h} \text { and } \\
18 \text {-fold higher after } 12 \mathrm{~h} .\end{array}$ & {$[50]$} \\
\hline Oseltamivir & IV & $\begin{array}{l}\text { Carbosilane } \\
\text { dendrimers with } \\
\text { hemagglutinin } \\
\text { binding peptide }\end{array}$ & $\begin{array}{l}\text { S i a l y l la ctose, } \\
\text { dichlorodimethylsilane, } \\
\text { trich lor o s i la n e, } \\
\text { dicyclohexylborane }\end{array}$ & $\begin{array}{l}\text { Mardin-Darby canine } \\
\text { kidney (MDCK) cell }\end{array}$ & $\begin{array}{l}\text { - Shows effectiveness against } \\
\text { human virus } \mathrm{A} / \mathrm{PR} / 8 / 34 \text { (H1N1) } \\
\text { and A/Aichi } / 2 / 68(\mathrm{H} 3 \mathrm{~N} 2) \text { with } \\
\text { IC50 values of } 0.60 \mu \mathrm{m}\end{array}$ & {$[51]$} \\
\hline
\end{tabular}

The molecular mechanism involved in the antiviral activities of transition metal includes multiple modes of action starting from inhibition of viral entry to inactivation of viral particles [52]. Fusion inhibition considers being a potential therapeutic intervention against this novel virus [69]. Xiang and coworkers reported the potential antiviral activity of silver nanoparticles (AgNPs) against the H3N2 influenza virus confirmed through both in vitro and in vivo models. The antiviral activity of AgNPs can be explained by their ability to inhibit hemagglutination activity [70]. Metal nanoparticle with multiple binding interactions has the potential to minimize the risk of multidrug resistance. Recently, Kim et al. established the superior target precision of surfactant-free porous gold nanoparticles for the conserved surface protein of the influenza virus. Experimental 
Table III. Size-Dependent Antiviral Activity of Inorganic NCs

\begin{tabular}{|c|c|c|c|c|c|c|}
\hline $\begin{array}{l}\mathrm{N} \text { a m e of } \\
\text { nanoparticle }\end{array}$ & $\begin{array}{l}\text { Size } \\
(\mathrm{nm})\end{array}$ & Virus & $\begin{array}{l}\text { Cell lin e } \\
\text { model }\end{array}$ & $\mathrm{IC}_{50} /$ Expt Conc & Target site for virus inhibition & Reference \\
\hline Ag NPs & $\begin{array}{l}30- \\
50\end{array}$ & HIV-1 & HeLa cell & $0.44 \mu \mathrm{g} / \mathrm{mL}\left(\mathrm{IC}_{50}\right)$ & Prevent virus entry & {$[56]$} \\
\hline Ag NPs & 10 & Feline calcivirus & CRFK cells & $\begin{array}{l}50 \text { and } 100 \mu \mathrm{g} / \mathrm{mL} \\
\text { achieved } 5.7 \text { and } 6.5 \\
\log _{10} \text { TCID50. }\end{array}$ & Viral inactivation & {$[57]$} \\
\hline Ag NPs & $8-12$ & Respiratory syncytial virus & $\begin{array}{l}\text { A } 549 \\
\text { epithelial cell }\end{array}$ & 1 mg/mL (Expt. Conc.) & $\begin{array}{l}\text { Binding to the surface of the } \\
\text { glycoprotein of the virus over the } \\
\text { respiratory epithelium }\end{array}$ & {$[58]$} \\
\hline Ag NPs & 25 & Monkeypox virus & Vero cells & $25 \mu \mathrm{g} / \mathrm{mL}$ & $\begin{array}{l}\text { Inhibit early steps of binding and } \\
\text { penetration by blocking virus-host } \\
\text { cell }\end{array}$ & {$[59]$} \\
\hline $\begin{array}{l}\text { A g N P s - } \\
\text { MHC }\end{array}$ & 30 & $\begin{array}{l}\text { Bacteriophage } \phi X 174, \\
\text { murine norovirus, and } \\
\text { adenovirus serotype } 2\end{array}$ & $\begin{array}{l}\text { MS2, RAW } \\
264.7 \text { cells, } \\
\text { A549 cells }\end{array}$ & $\begin{array}{l}2 \log 10 \text { after exposure } \\
\text { to } 4.6 \times 10^{9}\end{array}$ & Damaging the viral coat protein & {$[60]$} \\
\hline $\begin{array}{l}\text { A u N P s } \\
\text { using garlic } \\
\text { extract }\end{array}$ & 6 & Measles virus & Vero cells & $\mathrm{EC}_{50}=8.8 \mu \mathrm{g} / \mathrm{ml}$ & $\begin{array}{l}\text { Inhibit viral infection by blocking } \\
\text { viral particles directly }\end{array}$ & {$[61]$} \\
\hline $\mathrm{Au}$ NPs & 30 & Influenza virus & $\begin{array}{l}\text { MDCK cell } \\
\text { lines }\end{array}$ & - & Interact with virus capsid & {$[62]$} \\
\hline $\mathrm{Au}$ NPs & 10 & HIV-1 & $\begin{array}{l}\mathrm{He} \text { La - CD } 4 \text { - } \\
\text { LT R - B - g a } 1 \\
\text { cell }\end{array}$ & 57 to $78 \mu \mathrm{g} / \mathrm{mL}$ & Inhibit HIV-1 fusion & {$[63]$} \\
\hline $\mathrm{Au}$ NPs & $8-17$ & $\begin{array}{l}\text { Peptide-food-and-mouth } \\
\text { disease virus }\end{array}$ & $\mathrm{BALB} / \mathrm{c}$ mice & - & Immunogenic property & {$[64]$} \\
\hline $\mathrm{ZnO}$ NPs & $\begin{array}{l}20- \\
50\end{array}$ & H1N1 influenza virus & $\begin{array}{l}\text { MDCK-SIAT }_{1} \\
\text { cell }\end{array}$ & $\begin{array}{l}\text { Viability } \geq 90 \% @ \\
75 \mu \mathrm{g} / \mathrm{mL}\end{array}$ & Inhibit progeny release & {$[65]$} \\
\hline $\mathrm{CuI}$ NPs & 160 & Influenza A virus & MDCK cells & $\begin{array}{l}50 \% \text { reduction of virus } \\
\text { titer@ } 17 \mu \mathrm{g} / \mathrm{ml}\end{array}$ & Inactivation of viral protein & {$[66]$} \\
\hline $\mathrm{CuO}$ NPs & 40 & Herpes simplex 1 & Vero cell & $83 \%$ of viral load & Interfere with the viral replication & {$[67]$} \\
\hline
\end{tabular}

findings indicate the viability of virus-infected MDCK cells increased to $96.8 \%$ after gold nanoparticle treatment against $33.9 \%$ cell viability in the control group [71]. While the antiviral potential against HSV-2 is related to the affinity of silver for the thiol groups of viral capsids, that prevents viral internalization [72]. Further, nanometals due to their large surface area trigger the production of free radicals through intracellular signaling networks, which eventually leads to the disruption of viral activity. The antimicrobial activity of $\mathrm{TiO}_{2}$ is largely related to the production of ROS including hydrogen peroxide and hydroxyl radicals. However, the literature suggests $\mathrm{TiO}_{2}$ possesses a weak antiviral activity characterized by extremely low clearance of viral load after 2-h exposure of $\mathrm{TiO}_{2}$ at a concentration of $1 \mathrm{~g} / \mathrm{L}$. However, silver doping significantly enhances the antiviral potential of $\mathrm{TiO}_{2}$ by increasing the formation of hydroxyl free radicals [73]. Kumar et al. reported the antiviral potential of zinc nanoparticles against the chikungunya virus. Experimental outcomes supported by RTPCR and adsorption studies revealed a 10-fold reduction in virus titer. Possible results could be attributed to the ability of zinc NPs to modulate virus transcription and change in membrane polarity induced by the negative charge of $\mathrm{ZnO}$ and positive charge of virus capsid [74]. Bekele and coworkers investigate the antiviral potential of silver nanoparticles of different sizes 10, 75, and $110 \mathrm{~nm}$ against feline calicivirus. Experimental findings supported by antiviral study and western blot analysis suggest $10-\mathrm{nm}$ particles at a concentration of 50 and
$100 \mu \mathrm{g} / \mathrm{mL}$ show significantly higher antiviral activities compared to 75- and 110-nm AgNPs [57]. Further, the surface properties of nanoparticles including surface charge, surface hydrophobicity, etc. play an important role in their antiviral activity. Meléndez and coworkers investigate the antiviral activity of nano-gold prepared by garlic extract against measles virus using quantitative real-time PCR and virucidal assay using Vero cells (ATCC® CCL-81 ${ }^{\mathrm{TM}}$ ). Experimental findings suggest an antiviral activity of $57.07 \%$ with modified gold nanoparticles at a concentration of $10 \mu \mathrm{g} / \mathrm{mL}$ against $46.43 \%$ and $6.96 \%$, respectively, for the selected precursors, i.e., auric chloride and garlic extract [61]. Similarly, Alghrair et al. investigate the antiinfluenza potential of Flu-Pep modified silver and gold nanoparticles in canine MDCK cells. Results indicate both functionalized nano-systems show good antiviral potential characterized by an IC50 value of $2.1 \mathrm{nM}$ but were less potent compared to FluPep itself with an IC50 value of 140 pM [75]. Moreover, the inherent antibacterial activity of metal nanoparticles could play a crucial role in the decrease of the risk of secondary bacterial (especially caused by gram-negative bacteria) infections associated with prolonged therapy or post-viral treatment. Loo et al. synthesized an AgNP with the particle size of $4.06 \mathrm{~nm}$ with minimum inhibitory concentration and minimum bactericidal concentration against Escherichia coli, Klebsiella pneumoniae, Salmonella typhimurium, and Salmonella enteritidis which were 7.8, 3.9, 3.9, and 3.9 and 7.8, 3.9, 7.8, and $3.9 \mu \mathrm{g} / \mathrm{mL}$, respectively [76]. Regardless of some positive outcomes, metal nanoparticles 
have been reported to cause toxicity. In general, the key pathways involved in metal nanoparticle toxicity are oxidative stress, increased expression of pro-inflammatory mediators, influencing enzymatic activities, and inhibition of detoxification pathways. Recently, Bao et al. based on their extensive investigation about the toxicity of silver nanoparticles of varying size on zebrafish concluded that long-term exposure to silver nanoparticles particularly particles with less than $20 \mathrm{~nm}$ might cause sex-dependent and organ-specific toxicity to adult zebrafish [77]. Therefore, the particle size distribution, shape, charge, surface hydrophobicity, cellular uptake, degree of opsonization by the host cell, etc., of the nanoparticles, are the key selective parameters that need to be critically monitored for optimum therapeutic outcomes, improved in vivo stability with no cytotoxicity.

However, the size of the NPs determines the method of cellular uptake. For example, NPs of the size range of $60-80 \mathrm{~nm}$ is uptaken by caveola-mediated endocytosis, particle size about $100 \mathrm{~nm}$ opts for clathrin-mediated endocytosis, and bigger NPs $(>100 \mathrm{~nm})$ are driven by micropinocytosis as shown in Fig. 2 b. For achieving optimum therapeutic outcomes, the requisite concentration of antiviral agents must available at the site of infections. Assessing the cellular site, particle size, and its distribution plays an important role as demonstrated in lipidbased NPs [78]. Literature reveals that particle size range 25$30 \mathrm{~nm}$ shows poor liver uptake which could be an appropriate dimension for the hepatotoxicity induced by drugs like zidovudines, lamivudine, emtricitabine, and tenofovir. Similarly, particle size between 200 and $300 \mathrm{~nm}$ is well accumulated in the spleen and liver. Such dimensional NPs could be an ideal choice for drug targeting viral infection associated with the spleen (mononucleosis), and liver (hepatitis A, B, C) [79]. In addition to the size, the shape of the NPs directly influences the cellular uptake. Evidence-based research demonstrates rod-shaped NPs show higher cellular uptake followed by spherical, cylindrical, and cubical. However, size with sub-100-nm spherical NPs shows an appreciable cellular uptake over the rod shape. Further, NPs of 50-nm diameter of each single-walled carbon nanotubes and gold nanoparticles (AuNPs) possess an endocytosis rate of $10^{-3}$ and $10^{-6} \mathrm{~min}^{-1}$ [80]. The endocytosis pathway is a ligand-dependent scavenger that entraps nanoparticulate and carries forward to lysosomes where the endocytosed particulate gets deteriorated followed by exocytosis. In contrast, transcytosis helps to retain the NPs in the cytoplasm by avoiding the endosomal uptake. For better activity, the encapsulated drug must release into the cytosolic compartment for a sustained period by availing the transcytosis process. This can be achieved by either surface functionalization of NPs with human IgG, pure DNA fragment, vitamin B12, etc., or uncoated with a $\mathrm{pH}-$ sensitive synthetic peptide. It has been noticed that the surface coating of AuNPs with polyethylene-glycol(PEG) resulted in efficient internalization in endosomes and cytosol. For example, surface-functionalized polymeric NPs with a portion of $\operatorname{IgG}$ (Fc part of immunoglobulin $G$ ) shows a substantial increase in the rate of transcytosis in Calu-3 airway epithelial cells [81]. Further, NPs coated with a polymer, poly(DL-lactide-co-glucoside), get easily endocytosed and escape from the endosome by altering the surface charge from negative to positive resulting in cytoplasmic delivery of incorporated drugs [82].

Moreover, NP coated with a stimuli response polymer like polyvinyl sulfonic acid, polymethacrylic acid, and poly(propyl acrylic acid) activates the proton pump which will reduce the endosomal $\mathrm{pH}$. To maintain the electric neutrality inside the cytosol, a parallel influx of $\mathrm{Cl}$ ions and water rush into the vesicle that swells up and eventually premature ruptures the endosomal vesicle which releases the cytosolic delivery of antiviral NPs. Such effect is called the "proton sponge effect" [83]. The naked NPs are prone to aggregation and risk of opsonization by phagocytosis or filtration in the liver, spleen, and kidney. This rapid and unspecific clearance by the immune system contributes to a reduction in retention time and limits bioavailability. The surface functionalization of NPs with several biocompatible molecules like polyethylene glycol (PEG), carbohydrates, acetyl groups, or protein moieties (arginine-glycine-aspartate (RGD) peptide, albumin) will reduce the risk of opsonization and extended the retention time [84].

\section{Organic Nanocarriers}

\section{Liposomes}

Liposomes are the self-assembled spherical vesicle with a diameter range from 10 to $1000 \mathrm{~nm}$ enclosed by a phospholipid bilayer with a central aqueous core. Depending upon the number of a phospholipid bilayer (lamellar), liposomes further dived into small unilamellar (20-100 nm), large unilamellar (100-500 nm), and multilamellar (500-5000 nm) [85]. Different types of lipids such as phosphatidylcholine, phosphatidylserine, diota-decyl dimethyl ammonium bromide/chloride (DODAB/C), dioleoyl trimethylammonium propane (DOTAP), 1-stearoyl-2-linoleoyl-sn-glycerol-3[phospho-L-serine] (sodium salt), and cholesterol are extensively used in the synthesis of various functional liposomes [86]. Cholesterol in the phospholipid matrix stabilizes the membrane and reduces the membrane permeability. Besides that, it provides extra flexibility that enables them to pass through the smallest arteriole and endothelial fenestration without being clot anatomically in the privileged site [52]. The amphiphilicity nature of liposomes is suitable for encapsulating both hydrophilic and hydrophobic drugs. Lamivudine and zidovudine are nucleoside reverse-transcriptase inhibitors used activity against human immunodeficiency virus type 1 (HIV-1). The poor water solubility and short half-life unable to decrease viral burden, the rapid development of resistance, and toxic side effects have limited their long-term therapeutic efficacy [53]. Gavini et al. synthesized lamivudine and zidovudine combined PEGylated stealth liposome with a particle size of $241 \mathrm{~nm}$, and percentage drug entrapment efficiency (\%EE) is about 56.21-71.92\% [87]. Further, the trace amount of cholesterol and long alkyl chain length phosphatidylcholines stabilizes the liposome due to stronger van der Waals interaction between the lipid chains which resulted in increases in the phase transition temperature. Curcumin and its derivatives show broad-spectrumin vitro antiviral activity against a variety of viruses including parainfluenza virus type 3 , feline infectious peritonitis virus, flock house virus, and respiratory syncytial virus, vesicular stomatitis virus, and herpes simplex virus. The poor aqueous solubility and high plasma protein affinity render its clinical outcomes. Loutfy et al. synthesized curcumin-embedded 
chitosan liposomes with IC50 $=8 \mu \mathrm{g} / \mathrm{mL}$ for curcumin and $25 \mu \mathrm{g} / \mathrm{mL}$ for the nanocomposite on Huh7 but was $25.8 \mu \mathrm{g} / \mathrm{mL}$ and $34 \mu \mathrm{g} / \mathrm{mL}$ on WISH cells. The liposomes show $100 \%$ inhibition of viral (hepatitis C virus genotype 4a) entry and replication suggesting for effective therapeutic agent [88]. The short biological half-life of antiviral drugs like zidovudine $(0.5-3 \mathrm{~h})$, stavudine $(1.3-1.4 \mathrm{~h})$, abacavir $(0.8-1.5 \mathrm{~h})$, and nelfinavir $(3.5-5 \mathrm{~h})$ is another barrier that limits their clinical efficiency. To address this issue, the NPs decorated with PEG, albumin, or Fc fusion technologies have been reported in the literature [89]. Jain et al. synthesized a PEGylated elastic liposomal of zidovudine that exhibited a better transdermal flux of $119.5 \pm 5.2 \mu \mathrm{g} / \mathrm{cm}^{2} / \mathrm{h}$ in comparison with the plain drug $99.8 \pm 5.8 \mu \mathrm{g} / \mathrm{cm}^{2} / \mathrm{h}$ across the rat skin. This experimental finding means a 27 -fold higher accumulation of zidovudine in lymphoid tissues after administration of PEGylated elastic liposomes as compared with the free drug [90]. For optimum therapeutic outcomes, the liposomal surface was modified with an anionic fusogenic lipid component such as cholesteryl hemisuccinate (CHEMS) and dioleoyl phosphatidylethanolamine (DOPE) or phosphatidic acid-enhanced fusion with the endosomal membrane. The surface negative resulted in the destabilization endosomal membrane in an acidic environment, which resulted in the delivery of antiviral therapeutics to the cytoplasmic compartment [91]. Viral infectivity without preloaded active pharmaceutical ingredients was inhibited by cationic liposomes loaded with stearyl amine (SA). An in vivo study was carried out in several mammalian cell lines, including A549 cells, that show a significant reduction in the viral load without any toxic effect. The antiviral potency of SA liposomes can further be altered by reducing the concentration of cholesterol, which increases the induced strong bond interaction with the viral capsid [92]. Further, recent advancement in the nano formulation leads to development of hybrid combination of carbon-based nanoparticles with liposomes. Ji et al. prepared a nanocarbon fullerene lipidosome (NCFL) that shows the dose-dependent comparable virucidal activity against influenza virus $\mathrm{H} 1 \mathrm{~N} 1$, as compared to positive control rimantadine hydrochloride. The experimental results suggest the maximal concentration and $50 \%$ toxic concentration (TC50) of the NCFL were 7 and $13.54 \mu \mathrm{g} / \mathrm{mL}$ respectively. Polyunsaturated liposomes (PLs) have been fabricated for use in in vivo drug delivery to obtain broad-spectrum antiviral NPs against a range of viral infections by especially targeting to the endoplasmic reticulum. These PLs have polyunsaturated fatty acids that alter the cellular cholesterol biosynthesis, which leads to antiviral activity [93]. Impacting on biosynthesis of cholesterol is one of the promising targets within cells infected many viruses including hepatitis $\mathrm{C}$, hepatitis $\mathrm{B}$ virus, and human immunodeficiency virus. Pollock et al. demonstrated that pretreatment with polyunsaturated ER-targeting liposomes reduces the viral loading of hepatitis $\mathrm{C}$ and human immunodeficiency virus by suppressing the plasm cholesterol level by altering the functionality of endoplasmic reticulum. The results concluded a significant decrease in the hepatitis $\mathrm{C}$ viral load by $94 \%$ (SD 1.7) $(P<0.001)$, and HIV load by $64 \%$ (SD 13.2) $(P=0.004)$ [94]. However, the delicate membrane of the liposomes is most often oxidized and hydrolyzed and converted into a leaky vesicular that pulls out the drug. Besides this, high production cost, short half-life, and thermodynamic instability are some crucial parameters that need to be critically evaluated.

\section{Dendrimer}

Dendrimers are the symmetrically multibranched arranged core-shell structures. The nanometric dimension, monodispersed, void-assisted cargo facility, controllable release potency, and improved translocation across epithelial and endothelial barriers make them a suitable carrier system for delivery of antiviral therapeutic $[95,96]$. The existence of multiple numerous peripheral functional groups facilitates a higher binding affinity towards the surface protein-ligand of the virus. Depending upon the surface charge, dendrimer may be categorized into polyanionic dendrimers that comprise the terminal groups' sodium carboxylate, hydroxyl, and succinamic acid, whereas polycationic dendrimers contain primary amines. The hydroxyl polyanionic set showed a 17.3629.75\% decrease in MERS-CoV plaque formation [97]. Polymers have high antiviral capacity due to their long chains and branches and their flexible molecular design. Dendrimer chemically synthesized in a stepwise manner by either divergent or convergent branching method which differ in their propagation of synthesis. Over the last two decades, many dendrimers have been developed, including polyamidoamine (PAMAM), poly(propylene imine) (PPI), poly(glycerol-co-succinic acid), poly(L-lysine) (PLL), poly(glycerol), poly(2,2-bis(hydroxymethyl)propionic acid), and melamine [98]. Polyester dendrimers are biodegradable and, depending on the hydrophobicity of the monomer, steric environment, and the behavior of functional groups within the dendrimers, their hydrolysis rates will differ dramatically. Polyamine and polyamide dendrimers, on the other hand, in in vivo experimental results show poor degradability which influences their accumulation in the body on exposure to long-term therapy [99]. The inner multibranched cargo compartment of the dendrimer facilitates the simultaneous delivery of multiple therapeutic against at the target site. The internal architecture of dendrimer is favorable for encapsulating a large number of hydrophobic antiviral drugs such as ritonavir and efavirenz with water solubility of $1.2 \mu \mathrm{g} / \mathrm{L}$ and $8.85 \mu \mathrm{g} / \mathrm{L}$ respectively. Pyreddy and coworkers synthesized a fifthgeneration efavirenz (EFV) which conjugates PEGylated PAMAM dendrimers by using ethylenediamine as a central core via Michael addition by divergent method and epichlorohydrin as a cross-linker. The result reflects a comparative evaluation drug release profile of two formulations PEGylated 5.0 G PAMAM dendrimers and non-PEGylated dendrimers loaded with EFV released $83.28 \%$ in $120 \mathrm{~h}$ and $93.7 \%$ in $48 \mathrm{~h}$ respectively. This shows a clear indication that PEGylated formulation illustrates a slow drug release pattern in comparison to the plain drug [100]. The poor aqueous solubility of retroviral drugs is a major concern for their effective clinical utility. Documentary evidence support that surface-functionalized dendrimer shows extended retention time with enhancing the cellular uptake efficiency. Carraher and coworkers evaluated poly(amine ethers) containing acyclovir against herpes simplex virus 1 and varicella-zoster. The result shows the potent virucidal activity of acyclovir is associated with the production of singlet oxygen free radicals that completely inhibit DNA and RNA replication [101]. Further, cross-linked polymeric nanohydrogels, made up of water-soluble and expandable polymers, can be quickly degraded by renal clearance into smaller fragments. By binding to the heparan sulfate proteoglycans on the host cell surface, these polymers may avoid the entry of the HSV-2 
virus into the host cells [102]. The possible mechanism for dendrimer-driven solubility is the hydrophobic interaction between the drugs and the hydrophobic interior core of the dendrimer, hydrogen bond formation, and electrostatic interaction between the terminal functional group interaction with the hydrophobes. Further solubilization of the dendrimer affects the generation, polymeric architecture, $\mathrm{pH}$, core functionality, temperature, etc. [103]. Chun et al. engineered methoxy-poly(ethylene glycol)-block poly(phenylalanine) amphiphilic copolymers consisting of encapsulated mir-323a in the core and favipiravir in the outer layer [104]. This polymer-carried dendrimer was evaluated against the influenza A virus. The results show a significant inhibitory response was observed with better drug loading efficiency in comparison with naked polymer-free drug delivery systems. Moreover, de Araujo et al. evaluated PAMAM's binding affinity to the dendritic cell (DC)-SIGN receptor. DC-SIGN serves as a high-affinity receptor for mannose glycans that are present on the surface of the virus. Therefore, PAMAM coded with mannose-focused carbohydrate and its derivatives indicated that an assembly of mannose with aryl group at the peripheral region is advantageous for DC-SIGN binding. HIV has a high density of mannose-alpha1 and 2-mannose motif on gp120. This updated PAMAM blocked the interaction between gp120 and DCs at $10 \mu \mathrm{M}$ intensively [105]. Lander et al. synthesized a G4 PAMAM dendrimer with a diameter of $45 \mathrm{~A}^{0}$ conjugated with sialic acid (SA), sialoside. The findings show that G4-SA inhibits the viral (H3N2) growth by 51-170-fold lower concentration than monomeric SA and sialoside [106]. Despite many advantages, applications of dendrimer are constricted due to their intrinsic toxicity profiling. The cationic dendrimers nonspecifically interact with negatively charged biological membrane which leads to membrane disruption vianano-hole formation, membrane thinning, and erosion. Overall, intensive care must be taken in the selection of dendrimer generation, the surface functional groups, and its modification which may yield a safe and effective drug delivery system.

\section{Solid Lipid Nanoparticles}

Solid lipid nanoparticles (SLNs) are nano-lipid structures with an average diameter of 10-1000 nm considered an alternative colloidal carrier system parallel to liposomes and lipid shell-based nanoparticles. The characteristics of SLNs include high physical strength; excellent biocompatibility; good tolerability; and improved stability, control, and target drug delivery, and safety, and availability decreased toxicity with better drug release profiles for lipophilic and hydrophilic drugs, making the nanocarrier a unique one [107]. The benefit of SLNs helps to incorporate the conventional formulation by minimizing some of their disadvantages. Low penetrability, poor bioavailability, less solubility, etc. make the antiviral drugs a major challenge that confines their clinical efficacy in drug delivery. The antiviral drugs with poor water solubility can be easily impregnated in the central solid lipid/fatty acid core. However, the drug entrapment efficiency is completely dependent upon the nature lipid/fatty acid matrix. For example, various fatty acids like palmitic acid, stearic acid, and tetradecanoic acid have been used for the preparation of SLN but central matrix prepared with steric acid shows the highest drug entrapment efficiency may be due to long fatty acid chain length [108]. The poor aqueous solubility of acyclovir resulted in inadequate drug bioavailability due to fast elimination from the systemic circulation that required frequent dosing. To improve the physicochemical parameters, Kondel and coworkers synthesized an acyclovir-embedded SLN by microemulsion method. The experimental findings reflect particle size of $131 \pm 41.41 \mathrm{~nm}$ (polydispersity index (PDI) of $0.30 \pm 0.014$ ) with drug loading and encapsulation efficiency of $90.22 \pm 1.18 \%$ and $67.44 \pm 6.21 \%$ respectively. The in vitro drug release profile in simulated intestinal fluid shows $100 \%$ in 7 days with potent antiviral activity against herpes zoster virus (EC50 value for acyclovir is $0.296 \mu \mathrm{M}$ and for the SLN is $0.003 \mu \mathrm{M}$ ) [109]. Similarly, ganciclovir (GAN) is used against cytomegalovirus infections which is associated with poor oral bioavailability (5-6\%) that required a high dose of $3 \mathrm{~g}$ per day in their treatment regimen. Balwani et al. prepared GAN-loaded SLNs by a double emulsion solvent evaporation method by using glyceryl monostearate as the solid lipid matrix, and tocopheryl polyethylene glycol succinate as the stabilizer. The optimized SLNs with a particle size of $151.95 \pm 0.41 \mathrm{~nm}$ and encapsulation efficiency of $37.86 \pm$ 0.72 were designed for biphasic drug release pattern with an initial burst followed by sustained release up to $8 \mathrm{~h}$ [110]. Then Rabindrababu et al. prepared the GAN with conjugation with chitosan and piperine to ameliorate the absorption effect. The experimental outcomes reveal the importance of surfactant and its impact on the drug release profile. The SLN formulation is composed of nanoparticulate of dimension $37.2 \mathrm{~nm}$ with zeta potential $-18.3 \mathrm{mV}$. The SLN formulation composed of surfactant poloxamer 188 shows better drug release as compared with formulation with Tween 80 . This might be due to the higher HLB value of Poloxamer 188 [< 24] than Tween 80 [6]. Hence, it might be concluded that the higher the percentage of the surfactant, the higher will be the degree of drug release [111]. HIV encephalitis is a major pathological consequence in the patient suffering from HIV. Protease inhibitors like atazanavir, lopinavir, saquinavir, and fosamprenavir have been used in routine treatment. However, low brain uptake and poor permeability to the bloodbrain barrier (BBB) are the major challenges that will determine the effectiveness of the treatment. To readdress this issue, Chattopadhyay et al. synthesized atazanavir-loaded SLNs by a thin-film hydration technique. The experimental findings show the particle dimension of a freshly prepared SLN is $167 \mathrm{~nm}$ with a zeta potential of $-18 \mathrm{mV}$. Considering the cellular uptake, the SLN-based atazanavir shows a significant accumulation approximately 3-4-fold higher in the brain tissue as compared with the plain drug [47]. Further, extending the challenges of drug delivery to brain cells, Kuo and $\mathrm{Su}$ demonstrated the impact of different conjugated carrier systems in crossing the BBB. Results deliberately explain the low-brain-uptake drugs stavudine, delavirdine, and saquinavir incorporated with poly butyl cyanoacrylate ( P B C A ) N P s, me th y l me th a c r y l a t e sulfopropylmethacrylate(MMA-SPM) NPs, and SLN. Experimental findings revealed that stavudine has loaded maximum followed by delavirdine, and saquinavir on PBCA and MMASPM. The BBB permeability inversely correlates with the particle size in a fixed drug carrier system. Moreover, the maximum permeability enhancement for stavudine was observed in the carrier order of PBCA $>$ MMASPM $>$ SLNs, whereas the carrier system preferences for delavirdine and 
saquinavir are observed to be PBCA $>$ SLNs $>$ MMA-SPM. Hence, the carrier system PBCA, MMA-SPM, and SLNs were found to be efficacious stavudine, delavirdine, and saquinavir, as BBB permeability enhanced by $3-16$-fold, indicating translational clinical utility for the treatment of AIDS [112]. Moreover, for achieving an effective therapeutic outcome, interruption in the functionality of P-glycoprotein efflux and altering first-pass metabolism are two crucial factors that determine the drug bioavailability. SLN loaded with lopinavir shows a 2.5 -fold increase in the oral bioavailability with improved storage stability $\left(4^{\circ} \mathrm{C}\right.$ for 4 months $)$ as compared with lopinavir solution. The suggestive elaboration for such increased bioavailability of lopinavir may be attributed to higher lymph delivery as evidence that a significant amount of lopinavir is observed to accumulate in the main lymph organs like the spleen [113]. A similar finding was observed by using Compritol® 888 ATO as a solid lipoid in the synthesis of lopinavir-loaded SLN. The result showed a delayed drug release pattern from the solid matrix in both $0.1 \mathrm{~N} \mathrm{HCl}(\mathrm{pH} 1.2)$ and phosphate buffer ( $\mathrm{pH}$ 6.8). The oral bioavailability of lopinavir at $0.1 \mathrm{~N} \mathrm{HCl}$ and phosphate buffer is found to be 3.6- and 4.9-fold increase as compared with the corresponding solution counterpart. The optimized drug concentration in the systemic circulation may be attributed due to bypassing the $\mathrm{P}$ glycoprotein efflux [114, 115]. However, poor loading capacity for hydrophilic drugs, risk of drug explosion, and leakage during storage conditions due to lipid polymorphism need to be critically addressed while dispensing for clinical practice.

\section{Inorganic Nanocarriers}

\section{Silver Nanoparticles}

Silver nanoparticles (AgNPs) are known for their broadspectrum antimicrobial activity against a variety of microorganisms including fungus, bacteria (gram positive and gram negative), and viruses (respiratory syncytial virus, hepatitis B, simplex virus, HIV-1, and retrovirus) [116]. The antimicrobial potential of AgNPs is related to their ability to attract an electron from the surrounding; as a result, silver interacts with a wide variety of biomolecules including respiratory enzymes, RNA and DNA, and viral protein which leads to cellular dysfunction and eventually causes microbial death [117]. The particle size of AgNPs plays a significant role in determining their antiviral potential. Smaller particles owing to their high free surface energy show increased dissolution, and transport activity eventually leads to greater antimicrobial activity. Literature evidence suggested that particle size less than $10 \mathrm{~nm}$ exhibited significant antiviral activity against HIV-1 as it strongly binds with sulfur-bearing residue of overexpressed gp120 glycoprotein of lipid membrane that restricts the fusion of virus with CD4 receptors of the host cell [118]. Lara and coworkers reported that AgNPs with a size range between 30 and $50 \mathrm{~nm}$ show an IC50 value of 0.44 to $0.91 \mathrm{mg} / \mathrm{ml}$ against a different strain of HIV-1 virus generated from luciferasebased antiviral assays [56]. Morris and his team reported improved antiviral and immunomodulatory performance of smaller AgNPs (10-12 nm) against the respiratory syncytial virus through a suitable animal model. The virucidal activity of synthesized AgNPs may be due to its ability to interact with the surface glycoprotein of the virus over respiratory epithelium, while the immunomodulatory effect of AgNPs is associated with the downregulation of pro-inflammatory cytokines like IL-6, IFN, and CCL5. Authors further reported that AgNPs at the dose of $50 \mu \mathrm{g} / \mathrm{ml}$ do not exhibit any cytotoxicity against A549 epithelial cells. These outcomes encourage scientists to use AgNPs as an adjunct for COVID19 treatment [58]. Similarly, Park et al. demonstrated the antiviral activity of AgNPs against bacteriophages, adenovirus accessed by a plaque assay, and real-time TaqMan PCR. Experimental findings revealed silver nanoparticles $(30 \mathrm{~nm})$ displayed the maximum efficacy for inactivating the viruses. The mechanism of antiviral activity involves the interaction between the silver ion and cystine-rich domain of the essential transmembrane component of the virus, and releases reactive oxygen species causing inactivation of the virus. In addition, it was reported that $\mathrm{Ag}+$ ion causes a shift in intracellular $\mathrm{pH}$ of the respiratory epithelium from acid to alkaline region, prevents the acid-dependent fusion activation of virus, is the key feature of AgNPs, and indeed is exploited for the treatment of viral infections [60]. Moreover, appropriate surface functionalization of AgNPs improves membrane permeability, stability, and catalytic potency for higher bioactivity. A synergistic antiviral effect may also be exerted by surface alteration. Polyphosphonium-oligochitosan (PQPOC)-decorated AgNPs demonstrated moderate to remarkable antiviral activity against $\mathrm{HAV}, \mathrm{NoV}$, and CoxB4. By preventing the interaction of the targeted virus with the host through electrostatic interaction between the cationic polymers and the virus's negatively charged binding sites, PQPOC may also serve as an efficient virus inhibitor [119]. Graphene oxide (GO)-AgNPs amalgamated two nanomaterials to evaluate the antiviral potency against feline $\mathrm{CoV}$ (FCoV) and infectious bursal disease virus infection (IBDV). The result shows a reduction of feline $\mathrm{CoV}$ (FCoV) infection by $25 \%$ and IBDV infection by $23 \%$. The molecular mechanism reflects the negatively charged GO sheets strongly interact with a positive charged viral lipid membrane. Moreover, silver ion forms a covalent interaction with the viral surface protein at the cellular level the AgNPs effectively occupy the viral receptors that inhibit the viral invasion to the host cell [120]. Recently, Lee and coworkers investigate the catalytic function of polyvinylpyrrolidone (PVP)-coated AgNPs $(100 \mathrm{~nm})$ against thiol-containing enzymes including GAPDH and MDH [121]. Tannic acid-modified mucoadhesive hydrogel based on AgNP characterized with a particulate dimension of $33 \pm 13 \mathrm{~nm}$ and zeta potential of $-52 \pm 8 \mathrm{mV}$ shows $20 \%$ more potent against herpes simplex virus 2 growth $(P \leq$ 0.01 ) in comparison to herpes simplex virus 1 which could be an appropriate nanoformulation for local administration vaginal viral infections [122]. Significant inhibitory effects against the respiratory syncytial virus (RSV) infection were shown by curcumin-functionalized AgNPs by decreasing viral titers from two orders of magnitude to non-toxic concentrations in host cells [123]. H1N1 influenza virus multiplication was synergistically prevented by zanamivir-loaded AgNPs. Results indicated that AgNPs strongly bind to the thiol group, which cause a sharp decrease in their activity. Reduction in reaction rate appears to be highly dependent on the concentration of silver ions. Interestingly, spike glycoprotein of SARS-CoV-2 has many cysteine residues, and supported 
the possible application of AgNPs to treat COVID-19 [124]. Recently, the antiviral activity of AgNPs against the monkeypox virus was established. Experimental outcomes indicated that AgNPs prevent the entry of tacaribe virus into the host cell through multiple mechanisms including interfering with virus RNA-dependent RNA polymerase, inhibition of host gene expression, inhibition of viral glycoprotein, and inhibition of intracellular replication of the virus [59, 125]. Although the AgNPs show good antimicrobial potential, they have unacceptable toxicity, which limits their application for the treatment of lung infection. Surface functionalization appears to be important approach to reduce nano-metal toxicity. Sun and coworkers reported that saturated surface capping with bovine serum albumin (BSA) and poly(N-vinyl2-pyrrolidone) (PVP) significantly reduce cytotoxicity of AgNPs at a concentration of $100 \mu \mathrm{g} / \mathrm{ml}$ [126]. A comparative analysis was carried out by $\mathrm{Lv}$ et al. to measure the strength of different nanomaterials including AgNPs, silver nanowires, and silver colloids, on transmissible gastroenteritis virus (TGEV)-infected swine testicle cells in a concentration range of 60 and $400 \mathrm{~nm}$. The result percentage reduction in virus titer at concentration range of $3.125-12.5 \mu \mathrm{g} / \mathrm{ml}$ reflects only AgNPs and the two types of Ag nanowires induced protection against TGEV [127]. These findings suggest that surface capping using an appropriate substance acts as a potential strategy to reduce the toxicity without affecting the efficacy of nanoparticle.

\section{Gold Nanoparticles}

Gold nanoparticles (AuNPs) owing to their distinct structural and functional properties offer a multiplex platform for the antimicrobial application. With excellent characteristics such as electrical, optical, mechanical, and biological properties, gold nanoparticles (AuNPs) attracted significant interest in the pharmaceutical industries [128]. Literature evidence reveals AuNPs exhibit broad-spectrum antimicrobial performance against a wide variety of microorganisms including both gram-positive and gram-negative bacteria and viruses such as HIV-1, influenza virus, hepatitis B virus, and herpes simplex virus [129]. The antiviral properties of the gold nanoparticle are related to the size-dependent response and local-field interaction between AuNPs with the cell wall of the virus. Literature suggests size $(7-70 \mathrm{~nm})$-dependent antiviral activity of AuNPs against influenza virus A/FM/1/47 (H1N1) in MDCK cell line. The experimental finding reveals gold nanoparticle up to $30 \mathrm{~nm}$ shows optimum antiviral activity whereas larger particles $(>30 \mathrm{~nm}$ ) show negligible or no antiviral activity, and suggests smaller size nanoparticles $(\leq 30 \mathrm{~nm})$ interacted strongly with viral capsid, which led to virus destruction [62]. The distinctive shape and size of AuNPs influence the cellular uptake and immune response of the host cells. Niikura et al. demonstrated the impact on immune responses of spherical, rod-, and cubic-shaped AuNPs with a dimension of $40 \mathrm{~nm}$ each encapsulated with West Nile infection envelope protein. Rod-shaped AuNPs were found to be more efficient in macrophage and dendritic cellular uptake than spherical or cubic-shaped AuNPs. This may be explained by the exposed larger surface area. However, both spherical and cubic AuNPs induced higher levels of inflammatory cytokines, such as TNF-a, IL-6, IL-12, and GM-CSF, while rod-shaped AuNPs induced higher secretions of inflammasome-related cytokines, such as IL-1 $\beta$ and IL-18. Therefore, the production of antibodies is not dependent on the efficacy of uptake, and different shapes of AuNPs might boost the immune responses of different pathways [130]. Moreover, surface modification plays an important role in AuNP antiviral activity; thus, researchers modified the AuNCs' surface with two distinct materials-histidine and sulfonate of mercaptoethane. Among these, AuNCs with histidine stabilization showed good inhibition of pseudorabies virus (PRV) proliferation [131]. Further, optimum antiviral activity, therefore, surfacefunctionalized with different molecules plays critical roles. In particular, organic sulfonates and sulfates have been used for their ability to attract the virus through capsid protein interaction and block the activity of HA. Sulfonatefunctionalized AuNPs showed a growing inhibition of influenza A compared to succinic acid-capped nanoparticles [119]. Recently, the global pandemic caused by the SARS virus contributed a major threat to the human population and continuously increase the fatality rate [132]. It was found that the SARS is capable of infecting the human through spike protein S1 and S2, where S1 helps to bind cell through dipeptidyl peptidase-4 receptor and S2 binds to the cell membrane through heptad repeat 1 (HR1) and heptad repeat 2 (HR2) leading to endocytosis. Huang and coworkers reported that the complex between natriuretic peptide and gold nanorods has shown to inhibit HR1/HR2-mediated membrane fusion between MERS-CoV and the host. These findings encourage the researcher to use AuNPs in the management of SARS infection since both MERS-CoV and SARS-CoV utilizes a common entry platform to enter into host cells [133]. Successful immunization looks to be an effective choice to fight against infections caused by influenza and coronavirus. It was reported that intranasal administration of antigen (r-trimetric influenza A/Aichi/2/68(H3N2) HA)-conjugated AuNPs exhibits strong cellular and humoral immune response [134]. Since most of the influenza virus is associated with surface glycoprotein hemagglutinin; therefore, AuNPs may be used as an effective adjunct for efficient vaccine design against influenza infections. Besides, Sekimukai et al. also reported the immunization potential of recombinant S-protein with or without AuNPs. Results suggest immunization with AuNPs at a low dose $(0.5 \mu \mathrm{g})$ shows improved immunological performance characterized by higher immunoglobulin $\mathrm{G}$ titer and reduced eosinophilic infiltration in the lungs. These observations further elucidate the potential of AuNPs as an antigen carrier and adjuvant against severe pneumonia-associated coronaviruses [135]. Kim and coworkers reported the antiviral activity of gold nanoparticles is partially related to their affinity for the thiolated domain of hemagglutinin, which represents a highly conserved fusion protein of the influenza virus. The result indicates the viability of virus-infected MDCK cells increased to $96.8 \%$ after AuNP treatment against $33.9 \%$ cell viability in the control group [71]. The possible mechanism of antiinfluenza action of AuNPs is attributed to its increased affinity for disulfide bond with HA which leads to inhibition of viral membrane fusion, confirmed by real-time RT-PCR [136]. Like the influenza virus, SARS also contains HA; therefore, this thoughtful evidence encourages scientists for 
the use of AuNPs as an adjunct for COVID-19 treatment. AuNPs are usually considered as nontoxic; however, small AuNPs (1.4 nm) capped with triphenylphosphine monosulfonate shows cytotoxicity due to the upregulation of stress-related gene following 6 and $12 \mathrm{~h}$ of incubation with IC50 concentration [137]. Pretreatment with an antioxidant or reducing agent like $\mathrm{N}$-acetyl cysteine can lead to depletion of cytotoxicity of AuNPs [138]. AuNP-PT's increased virolytic activity and corresponding irreversible inactivation of HIV-1 is due to multivalent interaction with the HIV-1 virus between nanoconjugates and metastable envelope spike(S) proteins. Soluble adjuvant (AuNP-M2e $+\mathrm{sCpG}$ ) conjugation of M2e peptide with AuNPs and $\mathrm{CpG}$ mediated activation of lung $\mathrm{B}$ cells and a substantial serum anti-M2e immunoglobulin G ( $\mathrm{IgG})$ response in mice $[139,140]$. Bai et al. claimed that the entry of the porcine reproductive and respiratory syndrome virus (PRRSV) into host cells was prevented by AuNCs. PRRSV's proliferation and protein expression were selectively inhibited by AuNCs [141].

\section{Copper Nanoparticles}

Copper nanoparticles ( $\mathrm{CuO}$ NPs) are a well-known catalytic nature, which has been extensively used to reduce the bacterial and virus population [142]. Literature suggests that increased oxidative stress of $\mathrm{Cu} 2+$ ion resulted in antiviral potential against all types of the virus such as HIV1, influenza, and herpes simplex [143]. Fujimori et al. demonstrate the antiviral activity of copper(I) iodide (CuI) nanoparticle $(160 \mathrm{~nm})$ against H1N1 influenza confirmed through plaque titration assay. The experimental result indicates NPs at a concentration of $17 \mu \mathrm{g}$ per milliliter over an incubation period of $1 \mathrm{~h}$ produce a dose-dependent reduction of virus titer. The possible mechanism of virus inactivation is related to the inactivation of surface glycoprotein such as HA and NA by hydroxyl radicals [66]. Similarly, another study on Vero cell line demonstrates CuO NPs of 40$\mathrm{nm}$ size reveal excellent antiviral potential against herpes simplex virus characterized by $83.3 \%$ reduction of virus load, attributed to the ability of CuO NPs to inhibit the viral fusion in host cells and inhibition of viral replication [67]. Regardless of its positive outcomes, copper nanoparticles have been reported to cause toxicity. The literature revealed $\mathrm{CuO}$ NPs show size-dependent cytotoxicity and genotoxicity in C57BL/ 6 mice cell line. Further in vivo toxicological findings suggest inhalation of $\mathrm{CuO}$ NPs induces pulmonary inflammation and fibrosis in a dose-dependent manner [144]. In another study, it was found that intratracheal instillation $\mathrm{CuO}$ NPs $(33 \mathrm{~nm})$ induces acute toxicity, inflammation, and edema in F344 male rats [145]. Irrespective of size-dependent toxicity, the distinctive advantages of $\mathrm{CuO}$ NPs against respiratory pathogens could make a significant impact on the management of virus infection. Copper ions (derived from sulfates or iodide salts) have been commonly used as antiviral agents, against many types of enveloped and non-enveloped viruses, including influenza virus herpes simplex virus, and hepatitis A virus. Their mechanism of action depends on the formation of $\mathrm{Cu}^{2+}$ ions that produce hydroxyl radicals (from soluble salts or nanoparticles) that completely inhibit the DNA/RNA replication [146].

\section{Zinc Oxide Nanoparticles}

Zinc oxide nanoparticles ( $\mathrm{ZnO}$ NPs) show strong reducing ability and excellent biocompatibility that have been extensively investigated for different medical conditions especially in the field of antimicrobial, cancer, and antiinflammatory [147]. The antimicrobial activity of ZnONPs is connected with their high surface-to-volume ratio, ensures strong electrostatic interactions between the NPs and cell wall of pathogen, and produces reactive oxygen species, and subsequent cell death [148]. Ghaffari and coworkers reported the antiviral activity of ZnO NPs against the H1N1 influenza virus using MDCK-SIAT1 cell lines in MTT and RT-PCR assay. The experimental finding indicates the antiviral activity of 52.2 percentage with post-exposure of $\mathrm{ZnO}$ NPs at a concentration of $75 \mu \mathrm{g} / \mathrm{ml}$ could be attributed to the ability to inhibit hemagglutinin and neuraminidase glycopeptide led to inhibition of virus replication process in the cell [65]. Kumar et al. reported the antiviral effect of $\mathrm{ZnO}$ NPs against the chikungunya virus using MA104 cell line by MTT and RTPCR assay. Results suggest ZnO NPs at a concentration of $5.15 \mathrm{pg}$ and $3.10 \mathrm{pg}$ experience cell viability of $50 \%$ and $90 \%$ respectively. The possible mechanism involved could be related to the capacity of $\mathrm{ZnO}$ NPs to inhibit viral RNA transcription and change in charge confirmation of the capsid protein of the chikungunya virus [74]. These mechanisms of $\mathrm{ZnO}$ NPs can be exploited for controlled inactivation of the SARS-CoV-2 virus. Further, the size and morphology of zinc nanoparticles affect the antiviral properties' 3D form of zinc oxide tetrapods which blocks the entry of herpes simplex virus into the cells that could be attributed to the ability of oxygen vacancy of tetrapods to engage viral fusion glycolprotein (heparan sulfate) as an attachment receptor to prevent the entry of virus. Recent development suggests human corona virus NL63 utilizes heparan sulfate as an attachment factor with host cell [149, 150].

\section{Challenges of NPs/NCs as Nanomedicines}

Nanotechnology-based drug delivery system offers improved physicochemical properties of the antiviral drugs with ameliorating the therapeutic responses incorporated with nanotoxicity, instability, and complexity in the scaling-up nanoformulations as mentioned in Fig. 3.

The nanodimension nature of the NPs (1-100 nm) shows a major contributional role in the incidence of nanotoxicity. Although particle size range of 1-6 $\mathrm{nm}$ can easily be eliminated by the renal excretion system, particle size greater than $6 \mathrm{~nm}$ could not be eliminated but rather accumulate in various vital organs like the liver, lungs, and spleen that leads to the development of severe adverse effects [151]. Particle size increases beyond $100 \mathrm{~nm}$ restrict the bone marrow absorption and larger than $300 \mathrm{~nm}$ are not feasible for systemic circulation. The nanoengineered NPs/NCs have high surface energy that provides great momentum to invade with cell membrane that leads to leakage of cytosolic components such as lactate dehydrogenase and luciferase, and finally, membrane disruption accelerates apoptosis [152]. The nanosized particulates have a greater surface-area-to-volume ratio that boosts up the chemical reactivity and biological activity. Co-exposure to antioxidant molecules such as ascorbic acids 


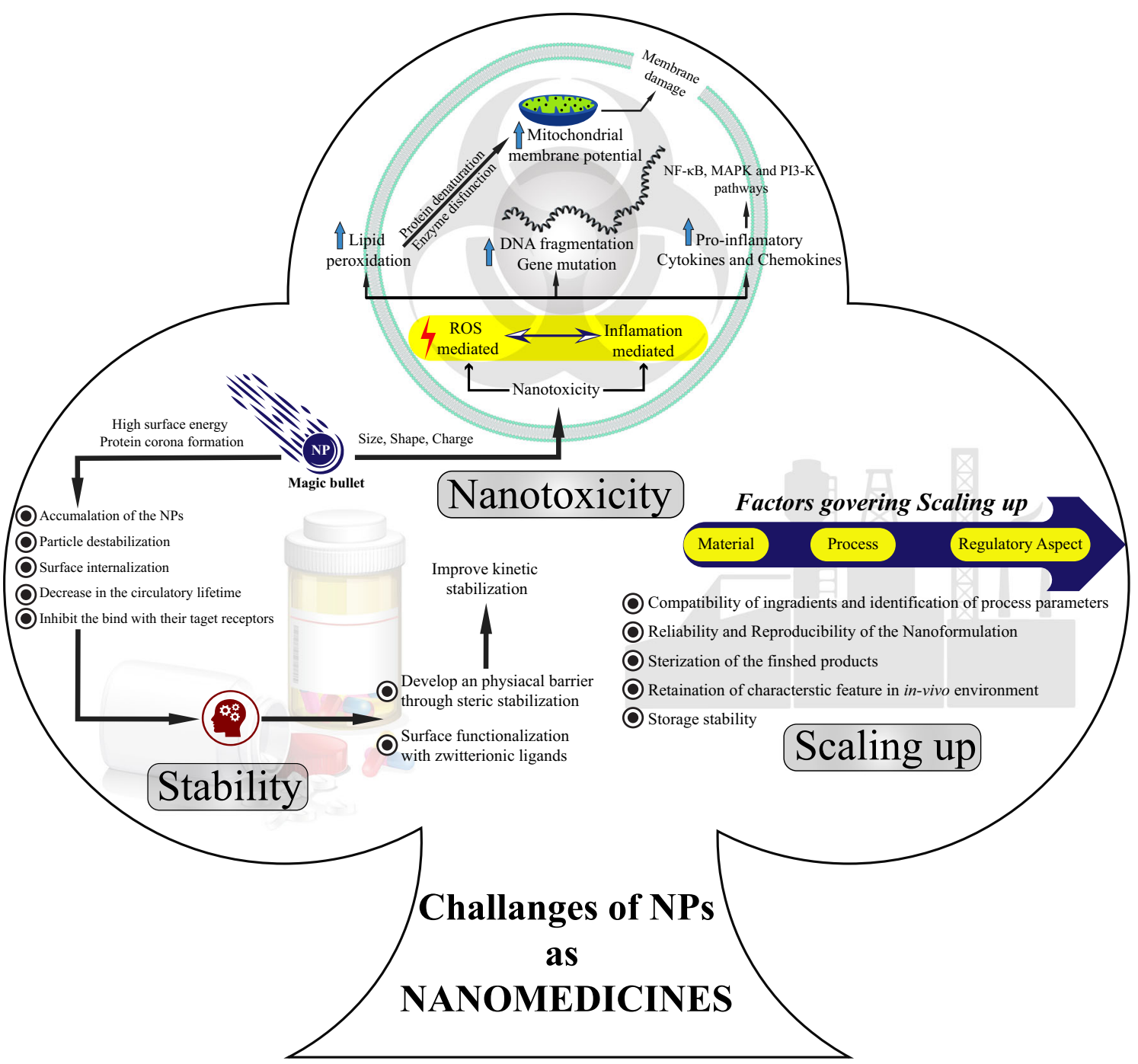

Fig. 3. A diagrammatic overlay on major key challenges in front of nanocarriers/nanoparticles to come out as nanomedicines

or plant flavonoids with strong free radical scavenging activity is one of the possible mechanistic approaches against oxidative stress-induced nanotoxicity [153]. The experimental findings demonstrated a drastic alteration in the ROS production on exposure to ascorbic acid along with the AgNPs against myeloid leukemia cells [154]. Further, various research publications insisted on the protective role of antioxidants along with concomitant exposure of NPs through regulating the mitochondria-induced apoptosis, mitigation of glutathione depletion, etc. However, the dose, selectivity, and specificity of the antioxidant selections over in vivo models may remain the key challenges to address further. Apart from it, polysaccharide polymers like chitosan-coated AgNPs have shown a decreased in vitro toxicity and ROS production with increased inflammatory responses [155]. Further, the shape and charge of the NPs play a supportive role in ameliorating the nanotoxicity. Experimental findings reveal that rodshaped NPs tend to accumulate more in the vital organs as compared with their counterpart shapes like spherical, cube, disc, and cylindrical [156]. Looking at the surface charge, positively charged NPs/NCs show greater non-specific cellular accumulation in comparison with the neutral and negatively charged NPs. The cationic NPs/NCs (AuNPs, dendrimer, etc.) have been shown to cause hemolysis and blood clotting to a greater extent as compared with the negative- and neutralcharged NPs/NCs. This could be explained by the electrostatic attraction between the negative charge cell membrane with the positive charge of the NPs [157]. Bhadra et al. suggested that surface-functionalized dendrimers with carbohydrate polymer resulted in a significant reduction in the hemolytic activity as compared with the uncoated dendrimer. The experimental findings showed $35.7 \%$ and $49.2 \%$ hemolytic toxicity associated with 4.0 and 5.0 PPI dendrimer, whereas galactose-coated dendrimer shows a great reduction in the hemolytic toxicity up to $10 \%$ and $7.1 \%$ in 4.0 and 5.0 PPI dendrimer respectively [158]. The stability of the NPs is the second prime challenge to address in the current research area of nanotechnology-based drug delivery. The high surface energy of the NPs and the inherent tendency of development of protein corona lead to sedimentation/accumulation in the nanoparticles, restrict the long circulation potency of the sterile NPs, and limit the binding efficiency NPs with the targeted receptors. The kinetic stability of the inorganic NPs depends upon the elemental ionization energy. For example, 
$\mathrm{Ag}$ is more easily oxidizable than $\mathrm{Au}$ as the ionization energy of silver is $7.58 \mathrm{eV}$ and $\mathrm{Au}$ has $9.23 \mathrm{eV}$. This could attribute to the more toxic effect of $\mathrm{Ag}$ in comparison with the $\mathrm{Au}$ at the same concentration [159]. However, surface functionalization with PEG, dextrose, and zwitterionic ligands (carboxybetaines, sulfobetaines, etc.), improves the stability profile by providing a steric short-range repulsive hydration layer around the NPs that impart long-term stability [160]. Moreover, in the last few decades, NP surfaces decorated with polyethylene glycol resulted in a significant reduction of nanotoxicity with better stability. Meanwhile, evidence-based research elaborates the repeated exposure of PEGylated NPs leads to the development of antibodies ( $\mathrm{IgG}$ and $\mathrm{IgM}$ ). In another research, it was found that frequent injection of PEGylated liposomes resulted in the loss of its stealth characteristics and as a consequence got cleared from the systemic circulation. This phenomenon is known as the "accelerated blood clearance" (ABC) [161]. Apart from it, inappropriate in vivo and in vitro data correlation is another crucial factor in front of standardization of the nanoformulation. The scale-up of a nanomedicine device from the bench to the market is the third most important front against NPs which emerges as nanomedicines. The nature of the ingredients, toxicological characteristics correlated with nanoparticle size and shape, in vivo biodegradability of nanocarriers, and dynamic balance among the process parameters are the various factors that govern the scalability of the nanoformulation. For example, in NPs' scale-up analysis prepared using the emulsion process, it was observed that particle size was decreased in impeller speed and agitation time, although the efficiency of the trap was not altered. Post-formulation treatment includes sterilization which often considered the most tedious task. Sterilization with autoclave is the most convenient and effective method used in the current practice. However, the high temperature and pressure during the sterilization may alter the structure and physicochemical properties of the NPs/NCs. It has been observed that higher temperature promotes the growth of gold NPs which may likely be due to the Oswald ripening process [162].

\section{CONCLUSION}

Recent developments in nanomedicine design and engineering have provided many privileges over the traditional approach of drug administration for the prevention and treatment of viral infections. The dominance of nanomedicine approaches lies in the presentation of unique attributes such as nanoscale dimensions, high surface-to-volume ratio, the versatility of surface functionalization to achieve the desired selectivity, and biocompatibility. Besides, nanoengineered NPs offer tremendous antiviral therapeutic potential by overwhelming the challenges of therapy resistance, low solubility, and drug bioavailability, erratic drug release, and short retention time of drugs in the plasm, etc. Further research is aimed at achieving a programmable multifunctional NPs of biocompatible and biodegradable nanomaterials to achieve site-specific, simultaneous delivery of multiple drugs and "multiplexing" in a heterogeneous population to enable the treatment of a wide spectrum of viral diseases and related comorbidities. An ongoing research is rooted against many life-threatening virus infections, and various nanotechnology-enriched NPs such as nanotraps, nanodiamonds, and nanofibers have found their way and can be further applied to other viral infections. The challenges involved in their manufacture and characterization and their large-scale processing are among the few obstacles to the production of these advanced types of nanomaterials. In the design of nanomaterials, the question of long-term toxicity and in vivo stability should be given paramount importance.

\section{ACKNOWLEDGMENTS}

The authors gratefully thank the SOA Institute for their support and encouragement.

\section{COMPLIANCE WITH ETHICAL STANDARDS}

Competing Interests The authors declare that they have no conflict of interest.

Abbreviations NCs, nanocarriers; AgNPs, silver nanoparticles; AuNPs, gold nanoparticles; Chol, cholesterol; CS, chitosan; Cys, cysteine; $D C$, dendritic cell; $D D S$, drug delivery system; $D L S$, dynamic light scattering; $D N A$, deoxyribonucleic acid; $D P P C$, dipalmitoylphosphatidylcholine; Epi, epirubicin; EPR, enhanced permeability and retention; $O A$, oleic acid; $P C$, phosphatidylcholine; $P E$, phosphatidylethanolamine; $P E G$, polyethylene glycol; $P G$, phosphatidylglycerol; $P O P C, 1-\mathrm{palmit}$ oy $1-2$ oleoylphosphatidylcholine; $P V A$, polyvinyl alcohol; $P V P$, polyvinylpyrrolidone; $R O S$, reactive oxygen species; $S L N$, solid lipid nanoparticle; $T G E V$, transmissible gastroenteritis virus; $T G F-\beta$, transforming growth factor; $\beta T N F-\alpha$, tumor necrosis factor $\alpha$; $G A N$, ganciclovir; $C H$, cholesterol; $A U C$, area under the curve; $N A D C$, sodium deoxycholate; $H I V$, human immune deficiency virus; PIs, protease inhibitors; $H S P C$, hydrogenated soy phosphatidylcholine; $m P E G-D S P E$, methoxy polyethyleneglycol-di-stearoyl-phosphatidylethanolamine; $D P P C$, dipalmitoyl phosphatidylcholine; $D P P G$, dipalmitoyl phosphatidyl glycerol; DSPE-PEG-MAL, distearoylphosphatidylethanolamine-[poly(ethyleneglycol)2000]maleimide; 14C-DPPC, L-3-phosphatidylcholine,1,2-di[1-14C]palmitoyl; $C M V$, cytomegalovirus; $A T V$, atazanavir; $E P C$, egg-phosphatidylcholine; $G M S$, glyceryl monostearate; $A C V$, acyclovir; $T F V$, tenofovir; AZT, zidovudine; PETIM, poly(propyl ether imine) dendrimers; $I V$, influenza viruses; $S A R S-C o V$, severe acute respiratory syndrome coronavirus; $M E R S-C o V$, Middle East respiratory syndrome coronavirus

\section{REFERENCES}

1. Colson P, Raoult D. Fighting viruses with antibiotics: an overlooked path. Int J Antimicrob Agents. 2016;48:349-52.

2. Zhang Y, Xu C, Zhang H, Liu GD, Xue C, Cao Y. Targeting Hemagglutinin: approaches for broad protection against the influenza A virus. Viruses. 2019;11.

3. Schloer S, Goretzko J, Pleschka S, Ludwig S, Rescher U. Combinatory treatment with oseltamivir and itraconazole targeting both virus and host factors in influenza a virus infection. Viruses. 2020;12.

4. Tempestilli M, Caputi P, Avataneo V, Notari S, Forini O, Scorzolini L, et al. Pharmacokinetics of remdesivir and GS441524 in two critically ill patients who recovered from COVID-19. J Antimicrob Chemother. 2020;75:2977-80.

5. Rosenbach KA, Allison R, Nadler JP. Daily dosing of highly active antiretroviral therapy. Clin Infect Dis. 2002;34:686-92. 
6. Leandro KC, Moreira JC, Farias PAM. Determination of zalcitabine in medicaments by differential pulse voltammetry. J Pharm. 2013;2013:1-6.

7. Ruane PJ, Richmond GJ, DeJesus E, Hill-Zabala CE, Danehower SC, Liao Q, et al. Pharmacodynamic effects of zidovudine $600 \mathrm{mg}$ once/day versus $300 \mathrm{mg}$ twice/day in therapy-naïve patients infected with human immunodeficiency virus. Pharmacotherapy. 2004;24:307-12.

8. Yuen GJ, Weller S, Pakes GE. A review of the pharmacokinetics of abacavir. Clin Pharmacokinet. 2008;47:351-71.

9. Marzolini C, Buclin T, Decosterd LA, Biollaz J, Telenti A. Nelfinavir plasma levels under twice-daily and three-timesdaily regimens: high interpatient and low intrapatient variability. Ther Drug Monit. 2001;23:394-8.

10. Kubin CJ, Hammer SM. Antiretroviral agents. Infectious Diseases [Internet]. Elsevier; 2010 [cited 2020 Dec 2]. p. 1434-53. Available from:https://linkinghub.elsevier.com/retrieve/pii/B9780323045797001453

11. Best BM, Goicoechea M. Efavirenz-stillfirst-line king? Expert Opin Drug Metab Toxicol. 2008;4:965-72.

12. Usach I, Melis V, Peris J-E. Non-nucleoside reverse transcriptase inhibitors: a review on pharmacokinetics, pharmacodynamics, safety and tolerability. J Int AIDS Soc. 2013;16:1-14.

13. Viani RM. Role of etravirine in the management of treatmentexperienced patients with human immunodeficiency virus type 1. HIV AIDS (Auckl). 2010; 2: 141-9.

14. Nadler JP, Gathe JC, Pollard RB, Richmond GJ, Liao Q, Griffith S, et al. Twice-daily amprenavir $1200 \mathrm{mg}$ versus amprenavir $600 \mathrm{mg} /$ ritonavir $100 \mathrm{mg}$, in combination with at least 2 other antiretroviral drugs, in HIV-1-infected patients. BMC Infect Dis. 2003:3:10.

15. Palma-Aguirre JA, Absalón-Reyes JA, Novoa-Heckel G, de Lago A, Oliva I, Rodríguez Z, et al. Bioavailability of two oral suspension and two oral tablet formulations of acyclovir 400 mg: two single-dose, open-label, randomized, two-period crossover comparisons in healthy Mexican adult subjects. Clin Ther. 2007;29:1146-52.

16. Jorga K, Reigner B, Chavanne C, Alvaro G, Frey N. Pediatric dosing of ganciclovir and valganciclovir: how model-based simulations can prevent underexposure and potential treatment failure. CPT Pharmacometrics Syst Pharmacol. 2019;8:167-76.

17. Reischig T, Hribova P, Jindra P, Hes O, Bouda M, Treska V, et al. Long-term outcomes of pre-emptive valganciclovir compared with valacyclovir prophylaxis for prevention of cytomegalovirus in renal transplantation. JASN. 2012;23:1588-97.

18. Else LJ, Jackson A, Puls R, Hill A, Fahey P, Lin E, et al. Pharmacokinetics of lamivudine and lamivudine-triphosphate after administration of 300 milligrams and 150 milligrams once daily to healthy volunteers: results of the ENCORE 2 study. Antimicrob Agents Chemothe. 2012;56:1427-33.

19. Jung YK, Yeon $\dagger \mathrm{JE}, \mathrm{Choi} \dagger \mathrm{JH}, \mathrm{Kim} \dagger \mathrm{CH}$, Jung $\dagger \mathrm{ES}, \mathrm{Kim} \dagger \mathrm{JH}$, et al Fanconi's syndrome associated with prolonged adefovir dipivoxil therapy in a hepatitis B virus patient gut liver 2010; 4:389-393.

20. Ridruejo E. Antiviral treatment for chronic hepatitis B in renal transplant patients. World J Hepatol. 2015;7:189-203.

21. Wang G, Liu Y, Qiu P, Zhou S-F, Xu L, Wen P, et al. Costeffectiveness analysis of lamivudine, telbivudine, and entecavir in treatment of chronic hepatitis B with adefovir dipivoxil resistance. Drug Des Devel Ther. 2015;9:2839-46.

22. Mirochnick M, Taha T, Kreitchmann R, Nielsen-Saines K, Kumwenda N, Joao E, Pinto J, Santos B, Parsons T, Kearney B, Emel L, Herron C, Richardson P, Hudelson SE, Eshleman SH, George K, Fowler MG, Sato P, Mofenson L, HPTN 057 Protocol Team Pharmacokinetics and safety of tenofovir in HIV-infected women during labor and their infants during the first week of life: JAIDS Journal of Acquired Immune Deficiency Syndromes 2014; 65:33-41.

23. Patterson KB, Prince HA, Kraft E, Jenkins AJ, Shaheen NJ, Rooney JF, et al. Penetration of tenofovir and emtricitabine in mucosal tissues: implications for prevention of HIV-1 transmission. Science Translational Medicine. 2011; 3:112re4-112re4.

24. Zhu L, Butterton J, Persson A, Stonier M, Comisar W, Panebianco D, et al. Pharmacokinetics and safety of twicedaily atazanavir $300 \mathrm{mg}$ and raltegravir $400 \mathrm{mg}$ in healthy individuals. Antivir Ther. 2010;15:1107-14.
25. Shuter J. Lopinavir/ritonavir in the treatment of HIV-1 infection: a review. TCRM. 2008;4:1023-33.

26. Martinez-Rebollar M, Lonca M, Perez I, Soy D, Brunet M, Martin R, et al. Pharmacokinetic study of saquinavir $500 \mathrm{mg}$ plus ritonavir (1000/100 mg twice a Day) in HIV-positive pregnant women: therapeutic drug monitoring. 2011; 33:772-7.

27. Shanmugam S, Im HT, Sohn YT, Kim KS, Kim Y-I, Yong CS et al. Zanamivir oral delivery: enhanced plasma and lung bioavailability in rats. Biomol Ther. 2013;21:161-9.

28. Pau AK, George JM. Antiretroviral therapy: current drugs. Infect Dis Clin N Am. 2014;28:371-402.

29. Namasivayam V, Vanangamudi M, Kramer VG, Kurup S, Zhan P, Liu X, et al. The journey of HIV-1 non-nucleoside reverse transcriptase inhibitors (NNRTIs) from lab to clinic. J Med Chem. 2019;62:4851-83.

30. Montessori V, Press N, Harris M, Akagi L, Montaner JSG. Adverse effects of antiretroviral therapy for HIV infection. CMAJ. 2004;170:229-38.

31. Banu B. Pneumonia. Reference Module in Biomedical Sciences [Internet]. Elsevier; 2019 [cited 2020 Sep 28]. p. B 9780128012383621000. Available from: https:// linkinghub.elsevier.com/retrieve/pii/B9780128012383621748

32. Zampino R, Mele F, Florio LL, Bertolino L, Andini R, Galdo $\mathrm{M}$, et al. Liver injury in remdesivir-treated COVID-19 patients. Hepatol Int. 2020;14:881-3.

33. Mulenga V, Musiime V, Kekitiinwa A, Cook AD, Abongomera G, Kenny J, et al. Abacavir, zidovudine, or stavudine as paediatric tablets for African HIV-infected children (CHAPAS-3): an open-label, parallel-group, randomised controlled trial. Lancet Infect Dis. 2016;16:169-79.

34. Mazumder S, Dewangan AK, Pavurala N. Enhanced dissolution of poorly soluble antiviral drugs from nanoparticles of cellulose acetate based solid dispersion matrices. Asian J Pharm Sci. 2017;12:532-41.

35. Chaudhary B, Verma S. Preparation and evaluation of novel in situ gels containing acyclovir for the treatment of oral herpes simplex virus infections. Sci World J. 2014;2014:1-7.

36. Vossen MTM, Westerhout EM, Söderberg-Nauclér C, Wiertz EJHJ. Viral immune evasion: a masterpiece of evolution. Immunogenetics. 2002;54:527-42.

37. Buzea C, Pacheco II, Robbie K. Nanomaterials and nanoparticles: sources and toxicity. Biointerphases. 2007;2:MR17-71.

38. Ghigo E, Kartenbeck J, Lien P, Pelkmans L, Capo C, Mege J$\mathrm{L}$, et al. Ameobal pathogen mimivirus infects macrophages through phagocytosis. Farzan M, editor. PLoS Pathog. 2008; 4:e1000087.

39. Tan A, Koh S, Bertoletti A. Immune response in hepatitis B virus infection. Cold Spring Harb Perspect Med. 2015;5:a021428.

40. Hagbom M, Nordgren J, Nybom R, Hedlund K-O, Wigzell H, Svensson L. Ionizing air affects influenza virus infectivity and prevents airborne-transmission. Sci Rep. 2015;5:11431.

41. Kondo J, Shimomura H, Fujioka S-I, Iwasaki Y, Takagi S, Ohnishi Y, et al. Mutations in the hepatitis B virus preS2 region and abrogated receptor activity for polymerized human albumin. Acta Med Okayama. 2002;56:193-8.

42. Strasfeld L, Chou S. Antiviral drug resistance: mechanisms and clinical implications. Infect Dis Clin N Am. 2010;24:413-37.

43. Shen Y, Tu J. Preparation and ocular pharmacokinetics of ganciclovir liposomes. AAPS J. 2007;9:E371-7.

44. Clayton R, Ohagen A, Nicol F, Del Vecchio AM, Jonckers THM, Goethals $\mathrm{O}$, et al. Sustained and specific in vitro inhibition of HIV-1 replication by a protease inhibitor encapsulated in gp120targeted liposomes. Antivir Res. 2009;84:142-9.

45. Gagné J-F, Désormeaux A, Perron S, Tremblay MJ, Bergeron MG. Targeted delivery of indinavir to HIV-1 primary reservoirs with immunoliposomes. Biochimica et Biophysica Acta (BBA)- Biomembranes. 2002; 1558:198-210.

46. Ren J, Zou M, Gao P, Wang Y, Cheng G. Tissue distribution of borneol-modified ganciclovir-loaded solid lipid nanoparticles in mice after intravenous administration. Eur J Pharm Biopharm. 2013;83:141-8.

47. Chattopadhyay N, Zastre J, Wong H-L, Wu XY, Bendayan R. Solid lipid nanoparticles enhance the delivery of the HIV 
protease inhibitor, atazanavir, by a human brain endothelial cell line. Pharm Res. 2008;25:2262-71.

48. Lv Q, Yu A, Xi Y, Li H, Song Z, Cui J, et al. Development and evaluation of penciclovir-loaded solid lipid nanoparticles for topical delivery. Int J Pharm. 2009;372:191-8.

49. Munoz-Fernandez MA, Ceña Diez R, Vacas-Córdoba E, García Broncano P, de la Mata FJ, Gómez R, et al. Prevention of vaginal and rectal herpes simplex virus type 2 transmission in mice: mechanism of antiviral action. IJN. 2016;2147.

50. Kumar S. In-vitro and in-vivo Evaluation of Poly (Propyl Ether Imine) (PETIM) Dendrimer for Sustained Delivery of Zidovudine. J Antivir Antiretrovir [Internet]. 2013 [cited 2020 Sep 30];05. Available from:https://www.omicsonline.org/ in-vitro-and-in-vivo-evaluation-of-poly-petim-dendrimer-forsustained-delivery-of-zidovudine-jaa.S10-004.php?aid=21492

51. Hatano K, Matsubara T, Muramatsu Y, Ezure M, Koyama T, Matsuoka K, et al. Synthesis and influenza virus inhibitory activities of carbosilane dendrimers peripherally functionalized with hemagglutinin-binding peptide. J Med Chem. 2014;57:8332-9.

52. Singh L, Kruger HG, Maguire GEM, Govender T, Parboosing $\mathrm{R}$. The role of nanotechnology in the treatment of viral infections. Ther Adv Infect Dis. 2017;4:105-31.

53. Li W, Wu J, Zhan P, Chang Y, Pannecouque C, De Clercq E, et al. Synthesis, drug release and anti-HIV activity of a series of PEGylated zidovudine conjugates. Int J Biol Macromol. 2012;50:974-80.

54. Simionescu BC, Ivanov D. Natural and synthetic polymers for designing composite materials. In: Antoniac IV, editor. Handbook of Bioceramics and Biocomposites [Internet]. Cham: Springer International Publishing; 2015 [cited 2020 Sep 28]. p. 1-54. Available from:https://doi.org/10.1007/978-3-319-09230-0_11-1

55. Iriarte-Mesa C, López YC, Matos-Peralta Y, de la VegaHernández K, Antuch M. Gold, silver and iron oxide nanoparticles: synthesis and bionanoconjugation strategies aimed at electrochemical applications. Top Curr Chem (Z). 2020; 378:12.

56. Lara HH, Ayala-Nuñez NV, Ixtepan-Turrent L, RodriguezPadilla C. Mode of antiviral action of silver nanoparticles against HIV-1. J Nanobiotechnol. 2010;8:1.

57. Bekele AZ, Gokulan K, Williams KM, Khare S. Dose and sizedependent antiviral effects of silver nanoparticles on feline calicivirus, a human norovirus surrogate. Foodborne Pathog Dis. 2016;13:239-44.

58. Morris D, Ansar M, Speshock J, Ivanciuc T, Qu Y, Casola A, et al. Antiviral and immunomodulatory activity of silver nanoparticles in experimental RSV infection. Viruses. 2019;11:732.

59. Galdiero S, Falanga A, Vitiello M, Cantisani M, Marra V, Galdiero M. Silver nanoparticles as potential antiviral agents. Molecules. 2011;16:8894-918.

60. Park S, Park HH, Kim SY, Kim SJ, Woo K, Ko G. Antiviral properties of silver nanoparticles on a magnetic hybrid colloid. Schottel JL, editor. Appl Environ Microbiol 2014; 80:2343-2350.

61. Meléndez-Villanueva MA, Morán-Santibañez K, MartínezSanmiguel JJ, Rangel-López R, Garza-Navarro MA, Rodríguez-Padilla C, et al. Virucidal activity of gold nanoparticles synthesized by green chemistry using garlic extract. Viruses. 2019;11:1111.

62. Lozovski V, Lysenko V, Piatnytsia V, Scherbakov O, Zholobak N, Spivak M. Physical point of view for antiviral effect caused by the interaction between the viruses and nanoparticles $\mathrm{j}$ bionanosci 2012; 6:109-112.

63. Vijayakumar S, Ganesan S. Gold nanoparticles as an HIV entry inhibitor. CHR. 2012;10:643-6.

64. Chen Y-S, Hung Y-C, Lin W-H, Huang GS. Assessment of gold nanoparticles as a size-dependent vaccine carrier for enhancing the antibody response against synthetic foot-andmouth disease virus peptide. Nanotechnology. 2010;21:195101.

65. Ghaffari H, Tavakoli A, Moradi A, Tabarraei A, BokharaeiSalim F, Zahmatkeshan M, et al. Inhibition of H1N1 influenza virus infection by zinc oxide nanoparticles: another emerging application of nanomedicine. J Biomed Sci. 2019;26:70.

66. Fujimori $Y$, Sato $T$, Hayata $T$, Nagao $T$, Nakayama $M$, Nakayama T, et al. Novel antiviral characteristics of nanosized copper(I) iodide particles showing inactivation activity against
2009 pandemic H1N1 influenza virus. Appl Environ Microbiol. 2012;78:951-5.

67. Drouet C. Nanotechnologies: a key role in virus fight. BJSTR [Internet]. 2020 [cited 2020 Sep 30];27. Available from:https:// biomedres.us/fulltexts/BJSTR.MS.ID.004500.php

68. Al-Halifa S, Gauthier L, Arpin D, Bourgault S, Archambault D. Nanoparticle-based vaccines against respiratory viruses. Front Immunol. 2019;10:22.

69. Zhang L, Liu Y. Potential interventions for novel coronavirus in China: a systematic review. J Med Virol. 2020;92:479-90.

70. Xiang D, Zheng C, Zheng Y, Li X, Yin J, O' Conner M, et al. Inhibition of A/human/Hubei/3/2005 (H3N2) influenza virus infection by silver nanoparticles in vitro and in vivo. IJN. 2013; 4103.

71. Kim J, Yeom M, Lee T, Kim H-O, Na W, Kang A, et al. Porous gold nanoparticles for attenuating infectivity of influenza A virus. J Nanobiotechnol. 2020;18:54.

72. Szunerits S, Barras A, Khanal M, Pagneux Q, Boukherroub R. Nanostructures for the inhibition of viral infections. Molecules. 2015;20:14051-81.

73. Thi Ngoc Dung T, Nang Nam V, Thi Nhan T, Ngoc TTB, Minh LQ, Nga BTT, et al. Silver nanoparticles as potential antiviral agents against African swine fever virus. Mater Res Express. 2020; 6:1250g9.

74. Kumar R, Sahoo G, Pandey K, Nayak MK, Topno R, Rabidas $\mathrm{V}$, et al. Virostatic potential of zinc oxide $(\mathrm{ZnO})$ nanoparticles on capsid protein of cytoplasmic side of chikungunya virus. Int J Infect Dis. 2018;73:368.

75. Alghrair ZK, Fernig DG, Ebrahimi B. Enhanced inhibition of influenza virus infection by peptide-noble-metal nanoparticle conjugates. Beilstein J Nanotechnol. 2019;10:1038-47.

76. Loo YY, Rukayadi Y, Nor-Khaizura M-A-R, Kuan CH, Chieng BW, Nishibuchi M, et al. In vitro antimicrobial activity of green synthesized silver nanoparticles against selected gramnegative foodborne pathogens. Front Microbiol. 2018;9:1555.

77. Bao S, Tang W, Fang T. Sex-dependent and organ-specific toxicity of silver nanoparticles in livers and intestines of adult zebrafish. Chemosphere. 2020;249:126172.

78. Crow MS, Lum KK, Sheng X, Song B, Cristea IM. Diverse mechanisms evolved by DNA viruses to inhibit early host defenses. Crit Rev Biochem Mol Biol. 2016;51:452-81.

79. Jr W, Pe O. Anti-retroviral drug hepatotoxicity and risk factors in HIV patients with or without hepatitis B and C: a review. J Infect Dis Ther [Internet]. 2015 [cited 2020 Sep 30];03. Available from:http://www.esciencecentral.org/journals/antiretroviral-drug-hepatotoxicity-and-risk-factors-in-hiv-patientswithor-without-hepatitis-b-and-c-a-review-2090-72141000258.php?aid $=65896$

80. Albanese A, Tang PS, Chan WCW. The effect of nanoparticle size, shape, and surface chemistry on biological systems. Annu Rev Biomed Eng. 2012;14:1-16.

81. Reinholz J, Landfester K, Mailänder V. The challenges of oral drug delivery via nanocarriers. Drug Delivery. 2018;25:1694-705.

82. De Jong WH, Borm PJA. Drug delivery and nanoparticles:applications and hazards. Int $\mathrm{J}$ Nanomed. 2008;3:133-49.

83. Chou LYT, Ming K, Chan WCW. Strategies for the intracellular delivery of nanoparticles. Chem Soc Rev. 2011;40:233-45.

84. Yetisgin AA, Cetinel S, Zuvin M, Kosar A, Kutlu O. Therapeutic nanoparticles and their targeted delivery applications. Molecules. 2020;25:2193.

85. Immordino ML, Dosio F, Cattel L. Stealth liposomes: review of the basic science, rationale, and clinical applications, existing and potential. Int J Nanomed. 2006;1:297-315.

86. Keservani RK, Sharma AK, editors. Nanoconjugate nanocarriers for drug delivery. Toronto ; New Jersey: Apple Academic Press; 2018.

87. Gavini V, Reddy RA, Mounika B, Prasanna AL, Sruthi S, Krishna BS. Combination therapy of lamivudine and zidovudine using sterically stabilized liposomes: development and characterization. Asian J Pharm. 2016;9:S31-8.

88. Loutfy SA, Elberry MH, Farroh KY, Mohamed HT, Mohamed AA, Mohamed EB, et al. Antiviral activity of chitosan nanoparticles encapsulating curcumin against hepatitis c virus genotype 4a in human hepatoma cell lines. IJN. 2020;15:2699-715. 
89. Swierczewska M, Lee KC, Lee $\mathrm{S}$. What is the future of PEGylated therapies? Expert Opin Emerg Drugs. 2015;20:531-6.

90. Jain S, Tiwary AK, Jain NK. PEGylated elastic liposomal formulation for lymphatic targeting of zidovudine. Curr Drug Deliv. 2008;5:275-81.

91. Biswas S, Torchilin VP. Nanopreparations for organellespecific delivery in cancer. Adv Drug Deliv Rev. 2014;66:2641.

92. Tahara K, Kobayashi M, Yoshida S, Onodera R, Inoue N, Takeuchi H. Effects of cationic liposomes with stearylamine against virus infection. Int J Pharm. 2018;543:311-7.

93. Gurunathan S, Qasim M, Choi Y, Do JT, Park C, Hong K, et al. Antiviral potential of nanoparticles - can nanoparticles fight against coronaviruses? Nanomaterials. 2020;10:1645.

94. Pollock S, Nichita NB, Bohmer A, Radulescu C, Dwek RA, Zitzmann N. Polyunsaturated liposomes are antiviral against hepatitis B and C viruses and HIV by decreasing cholesterol levels in infected cells. Proc Natl Acad Sci. 2010;107:17176-81.

95. Janaszewska A, Lazniewska J, Trzepiński P, Marcinkowska M, Klajnert-Maculewicz B. Cytotoxicity of dendrimers. Biomolecules. 2019;9.

96. Thiagarajan G, Ray A, Malugin A, Ghandehari H. PAMAMcamptothecin conjugate inhibits proliferation and induces nuclear fragmentation in colorectal carcinoma cells. Pharm Res. 2010;27:2307-16.

97. Kandeel M, Al-Taher A, Park BK, Kwon H, Al-Nazawi M. A pilot study of the antiviral activity of anionic and cationic polyamidoamine dendrimers against the Middle East respiratory syndrome coronavirus. J Med Virol. 2020;92:1665-70.

98. Jia F, Liu X, Li L, Mallapragada S, Narasimhan B, Wang Q. Multifunctional nanoparticles for targeted delivery of immune activating and cancer therapeutic agents. J Control Release. 2013;172:1020-34.

99. Venkataraman S, Hedrick JL, Ong ZY, Yang C, Ee PLR, Hammond PT, et al. The effects of polymeric nanostructure shape on drug delivery. Adv Drug Deliv Rev. 2011;63:1228-46.

100. Pyreddy S, Kumar PD, Kumar PV. Polyethylene glycolated PAMAM dendrimers-Efavirenz conjugates. Int J Pharm Investig. 2014:4:15-8.

101. Carraher CE, Sabir TS, Roner MR, Shahi K, Bleicher RE, Roehr JL, et al. Synthesis of organotin polyamine ethers containing acyclovir and their preliminary anticancer and antiviral activity. J Inorg Organomet Polym Mater. 2006;16:249-57.

102. Mazzon M, Marsh M. Targeting viral entry as a strategy for broad-spectrum antivirals. F1000Res. 2019;8:1628.

103. Choudhary S, Gupta L, Rani S, Dave K, Gupta U. Impact of dendrimers on solubility of hydrophobic drug molecules. Front Pharmacol. 2017;8:261

104. Chun H, Yeom M, Kim H-O, Lim J-W, Na W, Park G, et al. Efficient antiviral co-delivery using polymersomes by controlling the surface density of cell-targeting groups for influenza A virus treatment. Polym Chem. 2018;9:2116-23.

105. de Araujo RV, Martinez L, Moreira FA. Analysis of the inclusion of quantitative methods for the improvement of the effectiveness of collection actions in a power utility. 2018 Simposio Brasileiro de Sistemas Eletricos (SBSE) [Internet]. Niteroi: IEEE; 2018 [cited 2020 Sep 30]. p. 1-6. Available from:https://ieeexplore.ieee.org/document/8395677/

106. Landers JJ, Cao Z, Lee I, Piehler LT, Myc PP, Myc A, et al. Prevention of influenza pneumonitis by sialic acid-conjugated dendritic polymers. J Infect Dis. 2002;186:1222-30.

107. Chakravarty M, Vora A. Nanotechnology-based antiviral therapeutics. Drug Deliv and Transl Res [Internet]. 2020 [cited 2020 Sep 30]; Available from:https://doi.org/10.1007/s13346020-00818-0

108. Diab R, Jaafar-Maalej C, Fessi H, Maincent P. Engineered nanoparticulate drug delivery systems: the next frontier for oral administration? AAPS J. 2012;14:688-702.

109. Kondel R, Shafiq N, Kaur IP, Singh MP, Pandey AK, Ratho RK, et al. Effect of acyclovir solid lipid nanoparticles for the treatment of herpes simplex virus (HSV) infection in an animal model of HSV-1 infection. PNT. 2019;7:389-403.
110. Kadum MN. Formulation and evaluation of Silymarin floating microspheres. Pharm Anal Acta [Internet]. 2015 [cited 2020 Sep 29];06. Available from:http://omicsonline.org/2153-2435/ 2153-2435-Pharmaceutica-2015_Posters-AcceptedAbstracts.digital

111. Ravindra Babu M, Ravi Prakash P, Devanna N. Absorption enhancement effect of piperine and chitosan on ganciclovir solid lipid nanoparticles: formulation, optimization and invivo pharmacokinetics. ijrps. 2019;10:1143-51.

112. Kuo Y, Su F. Transport of stavudine, delavirdine, and saquinavir across the blood-brain barrier by polybutylcyanoacrylate, methylmethacrylate-sulfopropylmethacrylate, and solid lipid nanoparticles. Int J Pharm. 2007;340:143-52.

113. Khan S, Baboota S, Ali J, Khan S, Narang R, Narang J. Nanostructured lipid carriers: An emerging platform for improving oral bioavailability of lipophilic drugs. Int J Pharma Investig. 2015;5:182.

114. Aji Alex MR, Chacko AJ, Jose S, Souto EB. Lopinavir loaded solid lipid nanoparticles (SLN) for intestinal lymphatic targeting. Eur J Pharm Sci. 2011;42:11-8.

115. Darwis Y, Ali Khan A, Mudassir J, Mohtar N. Advanced drug delivery to the lymphatic system: lipid-based nanoformulations. IJN. 2013;2733.

116. Kerry RG, Malik S, Redda YT, Sahoo S, Patra JK, Majhi S. Nano-based approach to combat emerging viral (NIPAH virus) infection. Nanomedicine. 2019;18:196-220.

117. Narayanan KB, Sakthivel N. Biological synthesis of metal nanoparticles by microbes. Adv Colloid Interf Sci. 2010;156:113.

118. Elechiguerra J, Burt JL, Morones JR, Camacho-Bragado A, Gao X, Lara HH, et al. Interaction of silver nanoparticles with HIV-1. J Nanobiotechnol. 2005;3:6.

119. Reina G, Peng S, Jacquemin L, Andrade AF, Bianco A. Hard nanomaterials in time of viral pandemics. ACS Nano. 2020;14:9364-88.

120. Chen Y-N, Hsueh Y-H, Hsieh C-T, Tzou D-Y, Chang P-L. Antiviral activity of graphene-silver nanocomposites against non-enveloped and enveloped viruses. IJERPH. 2016;13:430.

121. Lee S, Jun B-H. Silver nanoparticles: synthesis and application for nanomedicine. IJMS. 2019;20:865.

122. Szymańska E, Orłowski P, Winnicka K, Tomaszewska E, Bąska $\mathrm{P}$, Celichowski G, et al. Multifunctional tannic acid/ silvernanoparticle-based mucoadhesive hydrogel for improved local treatment of HSV infection: in vitro and In vivo studies. IJMS. 2018;19:387.

123. Yang XX, Li CM, Huang CZ. Curcumin modified silver nanoparticles for highly efficient inhibition of respiratory syncytial virus infection. Nanoscale. 2016;8:3040-8.

124. Hati S, Bhattacharyya S. Impact of thiol-disulfide balance on the binding of Covid-19 spike protein with angiotensin converting enzyme 2 receptor [Internet]. Biochemistry. 2020 May. Available from:. https://doi.org/10.1101/ 2020.05.07.083147.

125. Koduru JR, Kailasa SK, Bhamore JR, Kim K-H, Dutta T, Vellingiri K. Phytochemical-assisted synthetic approaches for silver nanoparticles antimicrobial applications: a review. Adv Colloid Interf Sci. 2018;256:326-39.

126. Zheng Y, Cloutier P, Hunting DJ, Sanche L. Radiosensitization by gold nanoparticles: comparison of DNA damage induced by low and high-energy electrons. J Biomed Nanotechnol. 2008;4:469-73.

127. Lv X, Wang P, Bai R, Cong Y, Suo S, Ren X, et al. Inhibitory effect of silver nanomaterials on transmissible virus-induced host cell infections. Biomaterials. 2014;35:4195-203.

128. Gupta A, Moyano DF, Parnsubsakul A, Papadopoulos A, Wang L-S, Landis RF, et al. Ultrastable and biofunctionalizable gold nanoparticles. ACS Appl Mater Interfaces. 2016;8:14096-101.

129. Aderibigbe B. Metal-based nanoparticles for the treatment of infectious diseases. Molecules. 2017;22:1370.

130. Niikura K, Matsunaga T, Suzuki T, Kobayashi S, Yamaguchi H, Orba Y, et al. Gold nanoparticles as a vaccine platform: influence of size and shape on immunological responses in vitro and in vivo. ACS Nano. 2013;7:3926-38. 
131. Du T, Cai K, Han H, Fang L, Liang J, Xiao S. Probing the interactions of CdTe quantum dots with pseudorabies virus. Sci Rep. 2015;5:16403.

132. El Zowalaty ME, Järhult JD. From SARS to COVID-19: a previously unknown SARS- related coronavirus (SARS-CoV2) of pandemic potential infecting humans - Call for a One Health approach. One Health. 2020;9:100124.

133. Huang X, Li M, Xu Y, Zhang J, Meng X, An X, et al. Novel gold nanorod-based HR1 peptide inhibitor for Middle East respiratory syndrome coronavirus. ACS Appl Mater Interfaces. 2019;11:19799-807.

134. Wang C, Zhu W, Luo Y, Wang B-Z. Gold nanoparticles conjugating recombinant influenza hemagglutinin trimers and flagellin enhanced mucosal cellular immunity. Nanomedicine. 2018;14:1349-60.

135. Sekimukai H, Iwata-Yoshikawa N, Fukushi S, Tani H, Kataoka M, Suzuki T, et al. Gold nanoparticle-adjuvanted $\mathrm{S}$ protein induces a strong antigen-specific $\mathrm{IgG}$ response against severe acute respiratory syndrome-related coronavirus infection, but fails to induce protective antibodies and limit eosinophilic infiltration in lungs. Microbiol Immunol. 2020;64:33-51.

136. Zeng Q, Langereis MA, van Vliet ALW, Huizinga EG, de Groot RJ. Structure of coronavirus hemagglutinin-esterase offers insight into corona and influenza virus evolution. PNAS. 2008;105:9065-9.

137. Pan Y, Leifert A, Ruau D, Neuss S, Bornemann J, Schmid G, et al. Gold nanoparticles of diameter $1.4 \mathrm{~nm}$ trigger necrosis by oxidative stress and mitochondrial damage. Small. 2009;5:2067-76.

138. Daems N, Penninckx S, Nelissen I, Van Hoecke K, Cardinaels $\mathrm{T}$, Baatout S, et al. Gold nanoparticles affect the antioxidant status in selected normal human cells. IJN. 2019;14:4991-5015.

139. Rosemary Bastian A, Nangarlia A, Bailey LD, Holmes A, Kalyana Sundaram RV, Ang C, et al. Mechanism of multivalent nanoparticle encounter with HIV-1 for potency enhancement of peptide triazole virus inactivation. J Biol Chem. 2015;290:529-43.

140. Tao W, Hurst BL, Shakya AK, Uddin MJ, Ingrole RSJ, Hernandez-Sanabria M, et al. Consensus M2e peptide conjugated to gold nanoparticles confers protection against H1N1, H3N2 and H5N1 influenza a viruses. Antivir Res. 2017;141:6272.

141. Bai Y, Zhou Y, Liu H, Fang L, Liang J, Xiao S. Glutathionestabilized fluorescent gold nanoclusters vary in their influences on the proliferation of pseudorabies virus and porcine reproductive and respiratory syndrome virus. ACS Appl Nano Mater. 2018;1:969-76.

142. Raha S, Mallick R, Basak S, Duttaroy AK. Is copper beneficial for COVID-19 patients? Med Hypotheses. 2020;142:109814.

143. Rai M, Deshmukh SD, Ingle AP, Gupta IR, Galdiero M, Galdiero S. Metal nanoparticles: the protective nanoshield against virus infection. Crit Rev Microbiol. 2016;42:46-56.

144. Lai X, Zhao H, Zhang Y, Guo K, Xu Y, Chen S, et al. Intranasal delivery of copper oxide nanoparticles induces pulmonary toxicity and fibrosis in C57BL/6 mice. Sci Rep. 2018;8:4499.

145. Yokohira M, Takeuchi H, Yamakawa K, Saoo K, Matsuda Y, Zeng $\mathrm{Y}$, et al. Bioassay by intratracheal instillation for detection of lung toxicity due to fine particles in F344 male rats. Exp Toxicol Pathol. 2007;58:211-21.

146. Shionoiri N, Sato T, Fujimori Y, Nakayama T, Nemoto M, Matsunaga $\mathrm{T}$, et al. Investigation of the antiviral properties of copper iodide nanoparticles against feline calicivirus. J Biosci Bioeng. 2012;113:580-6.

147. Jiang J, Pi J, Cai J. The advancing of zinc oxide nanoparticles for biomedical applications. Bioinorg Chem Appl. 2018;2018:1-18.

148. Król A, Pomastowski P, Rafińska K, Railean-Plugaru V, Buszewski B. Zinc oxide nanoparticles: synthesis, antiseptic activity and toxicity mechanism. Adv Colloid Interf Sci. 2017;249:37-52.

149. Siddiqi KS, ur Rahman A, Tajuddin, Husen A. Properties of zinc oxide nanoparticles and their activity against microbes. Nanoscale Res Lett. 2018;13:141.

150. Milewska A, Zarebski M, Nowak P, Stozek K, Potempa J, Pyrc K. Human coronavirus NL63 utilizes heparan sulfate proteoglycans for attachment to target cells. J Virol. 2014;88:1322130 .

151. Makhdoumi P, Karimi H, Khazaei M. Review on metal-based nanoparticles: role of reactive oxygen species in renal toxicity. Chem Res Toxicol. 2020;33:2503-14.

152. Chan FK-M, Moriwaki K, De Rosa MJ. Detection of necrosis by release of lactate dehydrogenase activity. In: Snow AL, Lenardo MJ, editors. Immune Homeostasis [Internet]. Totowa, NJ: Humana Press; 2013 [cited 2020 Dec 2]. p. 65-70. Available from: https://doi.org/10.1007/978-1-62703-290-2_7

153. Schieber M, Chandel NS. ROS function in redox signaling and oxidative stress. Curr Biol. 2014;24:R453-62.

154. Abdal Dayem A, Hossain M, Lee S, Kim K, Saha S, Yang G$\mathrm{M}$, et al. The role of reactive oxygen species (ROS) in the biological activities of metallic nanoparticles. IJMS. 2017;18:120.

155. Hassanen EI, Khalaf AA, Tohamy AF, Mohammed ER, Farroh KY. Toxicopathological and immunological studies on different concentrations of chitosan-coated silver nanoparticles in rats. IJN. 2019;14:4723-39.

156. Liu Y, Tan J, Thomas A, Ou-Yang D, Muzykantov VR. The shape of things to come: importance of design in nanotechnology for drug delivery. Ther Deliv. 2012;3:181-94.

157. Harpe KM de la, Kondiah PPD, Choonara YE, Marimuthu T, Toit LC du, Viness Pillay. The hemocompatibility of nanoparticles: a review of cell-nanoparticle interactions and hemostasis. Cells. 2019;8:1-25.

158. Bhadra D, Bhadra S, Jain S, Jain NK. A PEGylated dendritic nanoparticulate carrier of fluorouracil. Int J Pharm. 2003;257:111-24.

159. Phan HT, Haes AJ. What does nanoparticle stability mean? J Phys Chem C. 2019;123:16495-507.

160. Guerrini L, Alvarez-Puebla R, Pazos-Perez N. Surface modifications of nanoparticles for stability in biological fluids. Materials. 2018;11:1154.

161. Kozma GT, Mészáros T, Vashegyi I, Fülöp T, Örfi E, Dézsi L, et al. Pseudo-anaphylaxis to polyethylene glycol (PEG)-coated liposomes: roles of anti-PEG IgM and complement activation in a porcine model of human infusion reactions. ACS Nano. 2019;13:9315-24.

162. França A, Pelaz B, Moros M, SÃ ¡nchez-Espinel C, Hern $\tilde{A}_{j}$ ndez A, Fern $\tilde{A}_{j}$ ndez-L $\tilde{A}^{3}$ pez C, et al. Sterilization matters: consequences of different sterilization techniques on gold nanoparticles. Small. 2010;6:89-95.

Publisher's NoteSpringer Nature remains neutral with regard to jurisdictional claims in published maps and institutional affiliations. 